\title{
Site suitability analysis for agricultural land use of Darjeeling district using AHP and GIS techniques
}

\author{
Malay Kumar Pramanik ${ }^{1}$
}

Received: 7 March 2016/ Accepted: 18 March 2016/Published online: 29 March 2016

(C) Springer International Publishing Switzerland 2016

\begin{abstract}
Darjeeling district covered with $60.89 \%$ of its land under Himalayan dense forest producing exquisite biodiversity and variations in climate with a diversified fauna and flora. Therefore, designs great scope for agricultural development in the rural area of the Himalayan foothills to boost rural economies. However, agriculture not mostly developed in this district due to different physical threats (such as very high slope and elevation, dense vegetation cover, fewer irrigation facilities, dry soil, etc.), socio-economic problems and lack of adequate transportation. Land suitability analysis can help to establish the strategies for the development of agricultural productivity. AHP with the integration of GIS-based multicriterion decision making an approach using DEM and Landsat 8 satellite data was utilized to evaluate land suitability for agriculture production in hilly areas. Various 'expert opinions' was used to determine the results of selected parameters whereas pairwise comparison matrix used to established the weights. About, $5.31 \%$ area is classified in the class highly suitable, $29.82 \%$ in moderately suitable, $24.27 \%$ in marginally suitable, and $40.60 \%$ in unsuitable for agriculture. The techniques, methodology and results of the study can be effective to assess the suitable land for agriculture in hilly regions.
\end{abstract}

Keywords Analytic hierarchy process - Agricultural land use suitability $\cdot$ Model builder toolbox · Darjeeling . Multi-criterion decision analysis $\cdot$ Moisture index

Malay Kumar Pramanik

malaygeo@gmail.com; malay65_ise@jnu.ac.in

1 CIPOD, School of International Studies, Jawaharlal Nehru University, New Delhi 110067, India

\section{Introduction}

Darjeeling district is famous for its fascinating hill station (Queen of the Hills) and tea garden. The economy of the region mainly depends on the tea industry and tourism. Besides tea, the most extensively cultivated crops include millets, maize, potato, ginger and cardamom. Therefore, pleasant climatic condition and rich biodiversity may lead to the development of agricultural activities, as well as rural tourism. The development of agricultural activities and management of rural tourism are necessary for the protection and conservation of natural resources with economic enhancement of the local villagers. Darjeeling district has been challenges of various natural disasters in recent times and unemployment that may promote the people's migration from hilly areas to the plains. Moreover, environmental problems due to tourism and land cover disturbance are major problems in hilly regions (Boori et al. 2014). Agricultural development and rural tourism can play a necessary role to make villagers selfsustainable as well as socio-economic development. Food safety and degradation of environmental quality concerns due to the unprecedented use of fertilizers, pesticides promoted the agricultural planning (i.e., organic farming) in recent times (Lapple and Cullinan 2012).

Land suitability analysis (LSA) is a method to encounter inherent and potential capabilities (Bandyopadhyay et al. 2009), and suitability for different objectives (FAO 1976). Land assessment measures the degree of land usefulness for potential land use by land requirement and qualities (FAO 1976; Hopkins 1977; Malczewski 2004). Multi-criterion evaluation (MCE) method is mostly applied for land suitability analysis. Multi-criterion evaluation of land suitability involves different criteria like geological and biophysical elements (i.e., geology, soil characteristics, 
Table 1 Techniques, parameters, fields and data used for land suitability mapping

\begin{tabular}{|c|c|c|c|c|}
\hline Suitability field & Techniques & Parameters & Data & References \\
\hline Land use & AHP & $\begin{array}{l}\text { Land-use capability class, soil depth, erosion hazard, elevation, } \\
\text { slope, distance from water source, limiting soil factors and distance } \\
\text { to road }\end{array}$ & Thematic maps & $\begin{array}{l}\text { Cengiz and } \\
\text { Akbulak } \\
(2009)\end{array}$ \\
\hline Agriculture & AHP & LULC, organic matter, soil depth, soil type and slope & $\begin{array}{l}\text { Satellite data: IRS- } \\
\text { 1D LISS-III and } \\
\text { thematic maps }\end{array}$ & $\begin{array}{l}\text { Bandyopadhyay } \\
\text { et al. (2009) }\end{array}$ \\
\hline $\begin{array}{l}\text { Rangeland } \\
\text { management }\end{array}$ & AHP & $\begin{array}{l}\text { Elevation, slope, climate, LULC, soil depth, soil hydrology, soil } \\
\text { texture, soil structure, erosion, vegetation density and types, } \\
\text { temperature, rainfall, distance from surface water and distance } \\
\text { from population centers }\end{array}$ & Thematic maps & $\begin{array}{l}\text { Jafari and } \\
\text { Zaredar (2010) }\end{array}$ \\
\hline Public parks & $\begin{array}{l}\text { AHP and } \\
\text { WLC }\end{array}$ & Available land, population density and land value & Thematic maps & $\begin{array}{l}\text { Chandio et al. } \\
\text { (2011) }\end{array}$ \\
\hline Agriculture & AHP & $\begin{array}{l}\text { Slope, elevation, aspect, soil } \mathrm{PH} \text {, soil fertility, precipitation, } \\
\text { temperature and groundwater }\end{array}$ & $\begin{array}{l}\text { Thematic maps, } \\
\text { SPOT } 5\end{array}$ & $\begin{array}{l}\text { Feizizadeh and } \\
\text { Blaschke } \\
(2012)\end{array}$ \\
\hline Agriculture & AHP & $\begin{array}{l}\text { Land use, soil depth, Soil groups, erosion, elevation, slope, aspect } \\
\text { and soil parameters }\end{array}$ & $\begin{array}{l}\text { Field base data and } \\
\text { thematic maps }\end{array}$ & $\begin{array}{l}\text { Akinci et al. } \\
\text { (2013) }\end{array}$ \\
\hline $\begin{array}{l}\text { Agricultural } \\
\text { product } \\
\text { warehouses }\end{array}$ & AHP & $\begin{array}{l}\text { Accessibility, security, Needs of the agricultural product warehouse, } \\
\text { security, accessibility, acceptance and costs }\end{array}$ & Thematic maps & $\begin{array}{l}\text { Garcia et al. } \\
\text { (2014) }\end{array}$ \\
\hline
\end{tabular}

relief, atmospheric conditions, vegetation etc.), as well as economic and socio-cultural conditions in decision making process (Joerin et al. 2001) to solving different land problems with multiple alternatives (Wang et al. 1990; Jankowski 1995; Yu et al. 2011). Geographical information system (GIS) is a useful technique to investigates the multiple geospatial data with precision and higher flexibility in land suitability analysis (Mokarram and Aminzadeh 2010; Mendas and Delali 2012). Therefore, multicriteria decision making (MCDM) process has been integrated with geospatial techniques in various studies for the potential land use decision-making process to solve complex problems of land management with best alternatives (Cengiz and Akbulak 2009; Malczewski 2006; Mendas and Delali 2012). This techniques extensively used for land suitability analysis to identify the potential lands for watershed management (Steiner et al. 2000), plantation (Zolekar and Bhagat 2014), agriculture (Shalaby et al. 2006; Bandyopadhyay et al. 2009; Jafari and Zaredar 2010; Cengiz and Akbulak 2009; Chandio et al. 2011; Feizizadeh and Blaschke 2012; Akinci et al. 2013; Garcia et al. 2014), etc.

Development of agricultural land use has a great potentiality in Darjeeling district due to its favorable environmental and climatic conditions. To acquire suitable land for maximum production, local geological and environmental conditions are essential factors. Identification of suitable sites for agricultural land use requires consideration of geophysical limitations, various topological and climatic environment (Kamkar et al. 2014; Bandyopadhyay et al. 2009; Feizizadeh and Blaschke 2012). Therefore, recent and accurate land use/land cover (LULC), and other environmental, geographical data should be considered for the determination of suitable agricultural land use (Wang 1994; Deep and Saklani 2014; Duc 2006). The parameters like LULC, slope, elevation, soil depth, soil moisture, soil texture, soil erosion, and soil nutrients are frequently used for assessment of land characteristics and suitability's for agricultural production (Table 1). Site suitability assessment of agricultural development includes the assessment of a large amount and variety of physiographic data, climatic characteristics (rainfall and temperature), internal soil condition (depth, moisture, texture, salinity and natural fertility), and external soil conditions (slope, accessibility and flooding) (Wang 1994). Geospatial techniques can be utilised for the identification of the suitable sites for the agricultural lands on different criteria like geology, topography, soil characteristics, drainage, and transport pattern of the study area. However, this technique can also use to prioritize and identify the potential sites for the agricultural land use pattern.

Further, Analytic hierarchy process (AHP) is extensively utilized for multi-criterion decision making of land suitability for the various field. It determines the weight of importance for different land use based on pairwise comparisons of various parameters according to their relative significance (Miller et al. 1998). Analytic hierarchy process 
was firstly developed by Saaty (1980), establish a hierarchical model for solving complex problems of land management with best alternatives (Malczewski 2006; Cengiz and Akbulak 2009; Roig-Tierno et al. 2013). As a multicriterion decision-making method, the analytic hierarchy process has been used widely for solving an extensive variety of problems based on complex parameters across various levels where the interaction among parameters is common characteristics (Tiwari et al. 1999).
Weighted overlay method (WOM) along with the analytic hierarchy process provides a very assuring outcome for the site suitability assessment of agricultural land use. The method can be useful to the multi-level hierarchical structure of various constraints and criteria (Triantaphyllou and Mann 1995). It has steps to analyze the relative influence of weights on each parameter, before obtaining the final score (Boroushaki and Malczewski 2008; Bunruamkaew and Murayam 2011). Analytical hierarchy

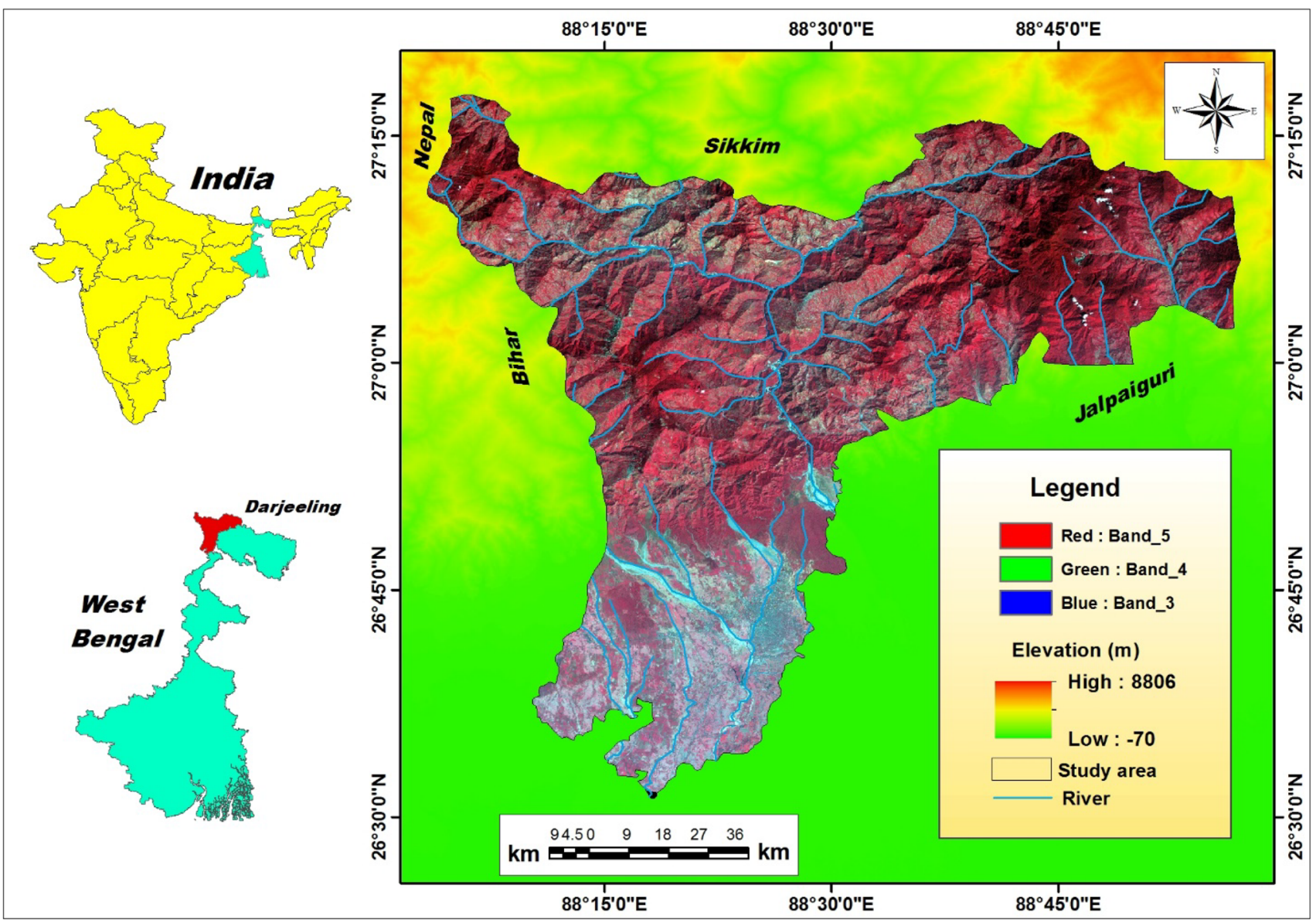

Fig. 1 Location map of the study area

Table 2 Parameter used in the habitat suitability indices and their types, details and sources

\begin{tabular}{lllll}
\hline Parameters & Data type & Data sources & Details about data & Period \\
\hline Slope, elevation, aspect & Spatial & SRTM DEM and Arc-GIS toolbox & 3-ARC (90 m) & 2000 \\
LULC & Spatial & OLI images & USGS satellite images \\
Soil moisture & Spatial & IR and Green band of OLI images & USGS satellite images \\
Drainage and transport network & Spatial & Digitized feature & Open street map and toposheets (SOI) & 2015 \\
Soil characteristics, geology & Spatial & Digitized feature & NATMO and GSI & 2015 \\
\hline
\end{tabular}


Fig. 2 Procedure followed in generating suitability map of agricultural production

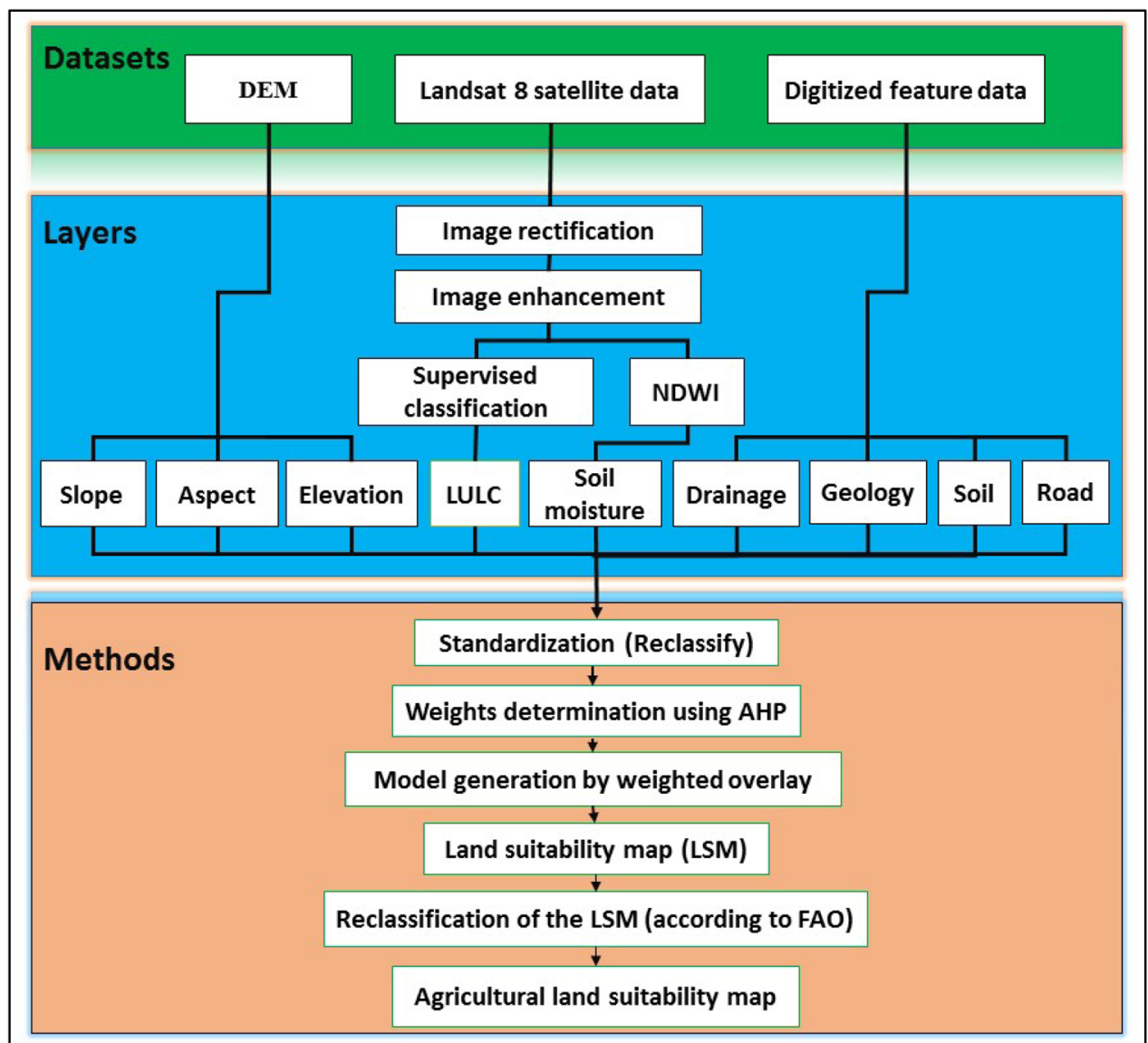

process is one of the auspicious method utilized for agricultural land suitability assessment based on individual parameters through quantitative assessment (Chen et al. 2010a, b; Akinci et al. 2013; Khahro et al. 2014). Pairwise comparison is also used to calculate the overall score of individual elements or criteria. Integration of GIS and analytical hierarchy process helps to decision support system by the generation of suitability maps (Khahro et al. 2014).

However, land use suitability and its mapping are one of the most effective utilizations of the geospatial techniques (Javadian et al. 2011). GIS techniques are also used to construct various criteria maps which are applied in analytical hierarchy process to formulate the site suitability model for agricultural development (Xu et al. 2012). The development of agriculture will not only improve the rural economy but also promote the diversification of poor farmers and rural tourism that can prevent the migration activity of poor people from hilly areas to the plain lands (Boori et al. 2014). Moreover, the very small land is available for agricultural development in the study area because of high variation in elevation and abundance of natural resources. The identification of suitable lands which is having the highest productivity as well as highest net profit on lesser input is expected and prioritized in the hilly areas. So, the suitability analysis of agricultural land is an appropriate and strong method for the hilly areas. The main objectives of the study are to identify the suitable lands for the agricultural development using GIS and analytic hierarchy process in the study area.

\section{Study area}

The study was carried out in the Darjeeling district, the northernmost part of the West Bengal (WB) in the foothills of the Eastern Himalayas, India. The study area is situated between the latitude $26^{\circ} 27^{\prime}$ to $27^{\circ} 13^{\prime} \mathrm{N}$ and longitude $87^{\circ} 59^{\prime} \mathrm{N}-88^{\circ} 53^{\prime} \mathrm{E}$, covering an area of $3149 \mathrm{~km}^{2}$ (Fig. 1). According to the census of 2011, the population of the district, which consists of 13 town and 139 villages, is 18,46,823. While 7,27,963 people live in urban areas, $11,18,860$ live in the villages. The population density of the district is 413 person $/ \mathrm{km}^{2}$ (District Census Handbook, Darjiling 2011).

The terrain of the study area is both plain and hilly. The elevation of the district varies from 15 and $3209 \mathrm{~m}$, and the elevation of mean sea level is approximately $750 \mathrm{~m}$ in the district center. The hill area is formed by recent rock 
Fig. 3 Elevation map of the study area

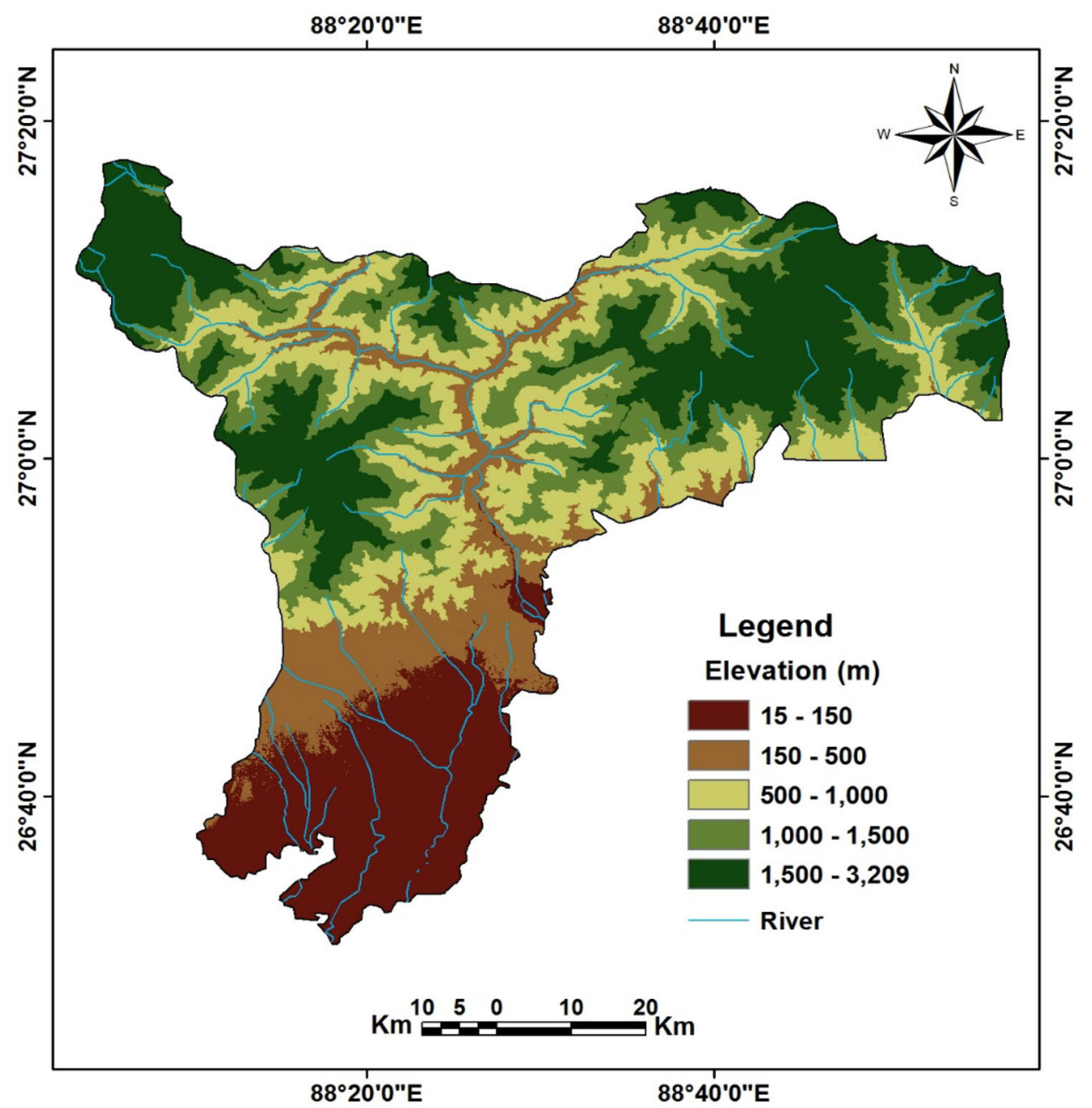

structure that has a direct potentiality to landslides by heavy monsoon precipitation. The soil of the Darjeeling hill regions is extremely varied, depending on geo lithology, the degree of slope, elevation, and vegetative cover.

The temperature of the region ranges from 14 to $24{ }^{\circ} \mathrm{C}$ in summer, and between 5 and $8{ }^{\circ} \mathrm{C}$ in winters (Darjeeling Climatological Table 1901-2000 2015). The hilly areas get heavy rainfall in the monsoon season. Rivulets and streams belonging to the Mahananda, Tista, Mechi, Balason, Jaldhaka, Rammam and Rangit river system flow in the northern portion of the region. The district is also important for the tourism and pilgrimage sites like Tiger Hill, Rock Garden, Mahakal Temple, Dhirdham Temple, Batasia Loop, Ghoom Monastery and Happy Vally Tea Garden, etc.

The economy of the Darjeeling hill region depends on horticulture, tea production, agriculture, tourism, and forestry. Recently, the maximum portion of forests are found at $2000 \mathrm{~m}$ elevations and above. The located area between 1000 and $2000 \mathrm{~m}$ elevations is cleared either for agricultural activities or tea plantation. The deep soils of
Himalayan foothill areas have the potentiality to plantations and agriculture.

\section{Materials and methods}

In the present study multi-criterion, site suitability modeling was developed to establish appropriate and potential locations for agricultural development based on a group of constraints and criteria. Depending on their significance and importance in the agriculture seven different constraints and criteria were selected. The identification of different criteria depended on maximum limitation method that influences the product yield of agriculture which includes geology, soil type, elevation, slope, aspects, drainage and distance from roads, etc. (Duc 2006; Akinci et al. 2013). Moreover, weights for the each selected criterion were estimated using analytical hierarchy process and after that weighted overlay method was adopted to establish the suitability map. Table 2 represents the data used, types, and sources for the agriculture site suitability 
Fig. 4 Slope of the study area

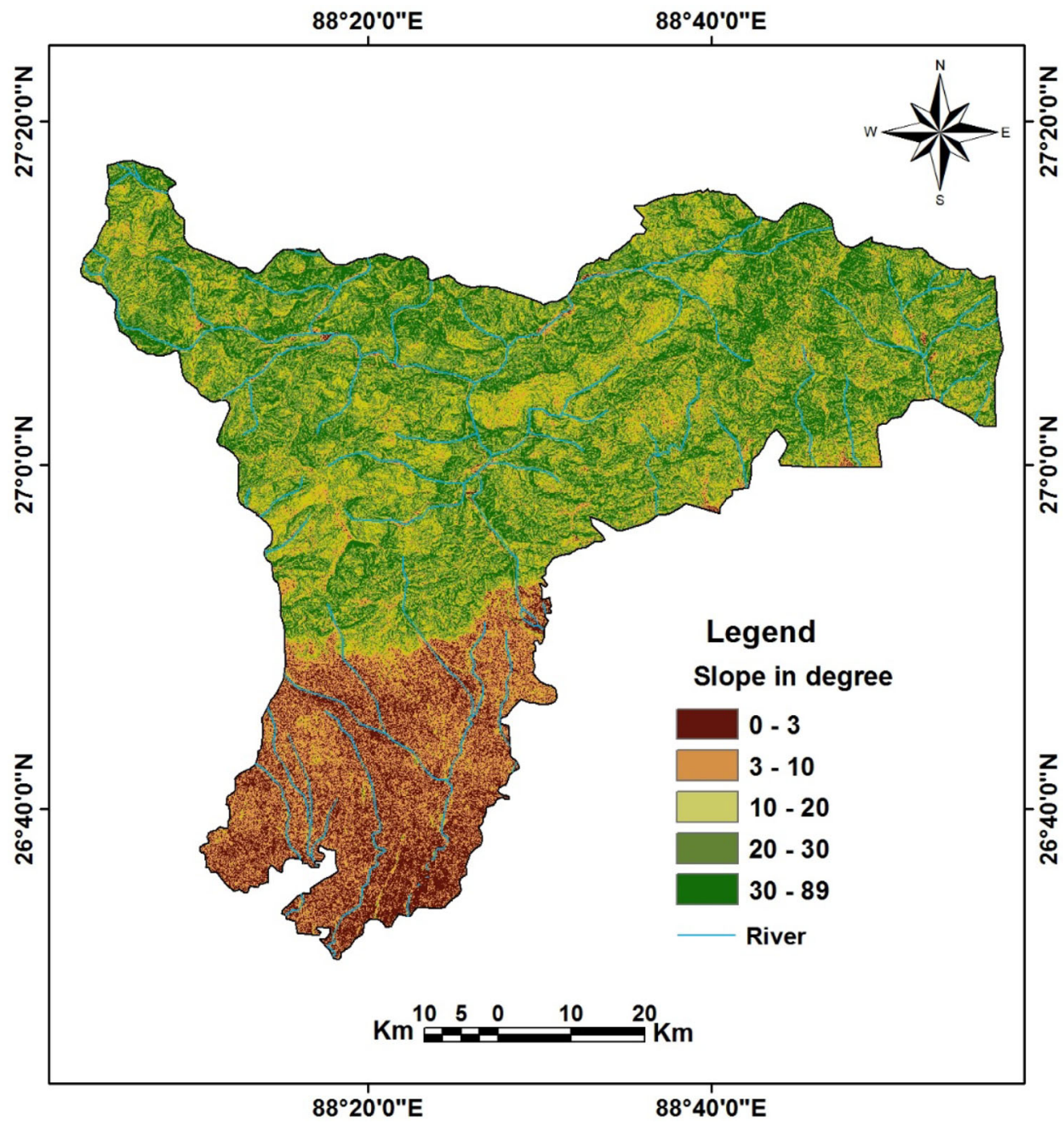

analysis. The methodological flow diagram of the present study is shown in Fig. 2.

\section{Generation of criterion maps using geospatial techniques}

Elevation (Fig. 3), slope (Fig. 4), and aspect (Fig. 5) map were generated using Shuttle Radar Topography Mission (SRTM) near-global Digital Elevation Models (DEMs) data of $90 \mathrm{~m}$ resolution obtained from United States Geological Survey (USGS). Geology (Fig. 6) and soil (Fig. 7) maps were derived using National Atlas and Thematic Mapping Organisation (NATMO) and Geological Survey of India (GSI) map. Drainage (Fig. 8) and road system (Fig. 9) maps were derived using an open street map and toposheets maps of Survey of India (SOI). Land use/land cover (LULC) map (Fig. 10) and Soil moisture map (Fig. 11) were prepared using Landsat 8 satellite images of $15 \mathrm{~m}$ spatial resolution. The moisture map was calculated by Normalised Difference Water Index (NDWI) which is measured using Infra-Red (IR) and Green (G) bands (Eq. 1) of Landsat 8 satellite images.

$N D W I=\frac{I R-G}{I R+G}$

\section{Standardization of selected criteria maps}

All of the selected criteria are in different units so to execute Weighted Overlay Method they require to be convert in same units and hence required to be standardized value. Standardization techniques convert the measurement to uniform units, and the resulted score lose their dimension along with their measurement unit of all criteria (Effat and Hassan 2013).

The vector layer of all criteria maps was converted to raster layer that has been shown in Fig. 12. After that, all raster layers were reclassified and used for the input data to 
Fig. 5 Aspect map of the Darjeeling district

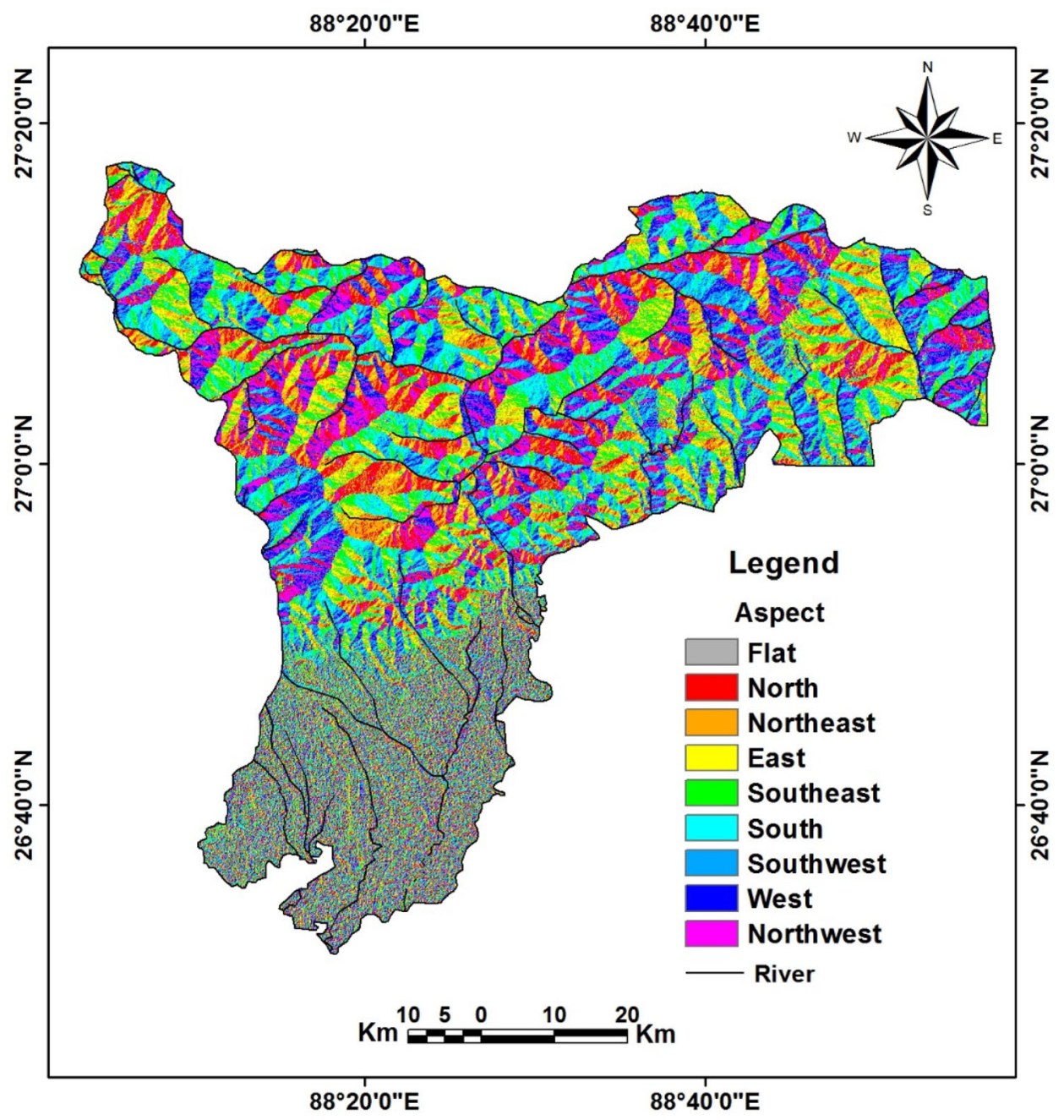

the weighted overlay method which finally create the suitability map for agriculture. Reclassify method in spatial analyst toolbox of Arc-GIS software, standardizes the value of all selected criteria for the analysis of comparative significance.

Agriculture requires good geology, and soil types with having drainage availability for the irrigation system, roads, and rails are also significant for the easy transportation facility of the raw products of agriculture. While Darjeeling is a mountainous district, elevation, slope and aspect come to the decision-making process (DMP) for identifying suitable land for agricultural development. For suitable site identification, all these parameters were considered during the analysis of potential agriculture zone. All parameters were reclassified in five different category. The sub-criterion were classified into 1-10 different ranking scales where 1 having the least significance and 10 having the highest significance (Table 3).

\section{Calculation of weight for each criterion}

Analytic hierarchy process is one of the most significant multicriteria decision-making techniques. The process is applied to a set of criteria or sub-criteria to establish a hierarchical structure by giving the weight of each criterion incomplete decision-making process (Kiker et al. 2005). The weight value analyzes the relative significance of individual criterion and hence to be chosen deliberately. Analytic hierarchy process gives a structural ground for quantifying the strong comparison of design criteria and elements in a pairwise technique and thus decreases the complexity of decision-making process (Miller et al. 1998; Saaty 1977). The process determines the weight values by pairwise comparison technique by relative significance of criterion, taken two at a time (Miller et al. 1998). Using the pairwise comparison matrix, the analytic hierarchy process calculates the weights for the individual criterion by taking the eigenvalue corresponding to the highest eigenvector of 
Fig. 6 Geology map of the Darjeeling district

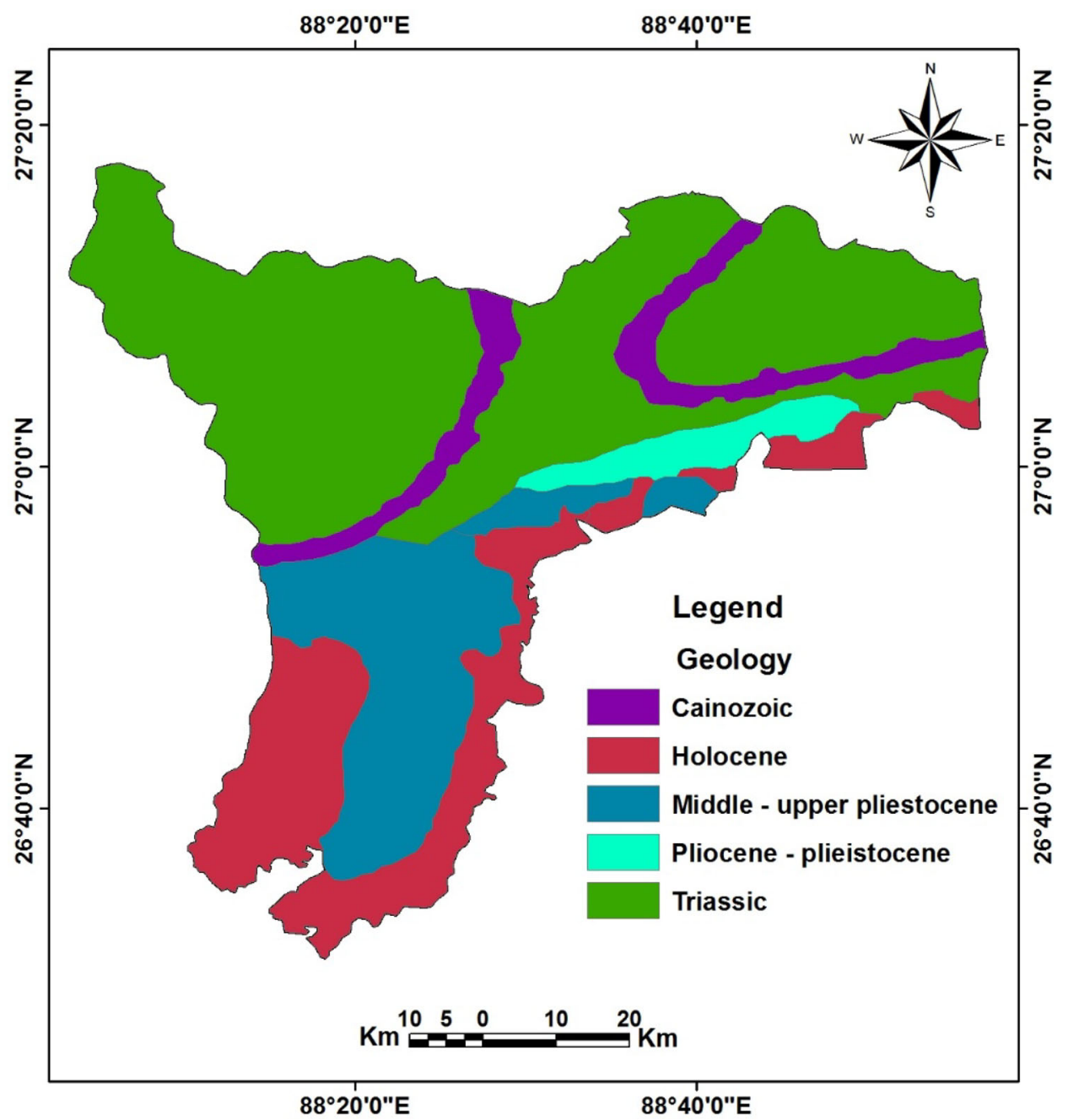

the completed matrix and the normalizing the sum of the factors to unity (Saaty 1980; Malczewski 1999; Feizizadeh et al. 2014).

Using the analytic hierarchy process explained above the pairwise comparison matrix was calculated using the scale of 1-9 where 9 indicates extreme significance and 1 indicates the equal significance of in between criterion of the matrix shown in Table 4 (Saaty 1980; Malczewski 1999; Feizizadeh et al. 2014). The comparison matrix mainly has the criteria of reciprocity which mathematically expressed as, $n(n-1) / 2$ for $n$ number of components in pairwise comparison matrix (Saaty 1980; Akinci et al. 2013). After the computation of pairwise matrix, relative weights/eigenvectors is calculated using Saaty's method (Saaty 1980) (Tables 5, 6). Moreover, analytic hierarchy process also identifies and calculate the inconsistencies of decision makers which is its one of the significant characteristics (Saaty 1980; Feizizadeh et al. 2014; Garcia et al. 2014). The efficiency criteria of analytic hierarchy process are estimated by consistency relationship (CR) which is measured by Eq. 2 .

$C R=C I / R I$

Equation 2 represents the CR where CI indicates consistency index and RI indicates the random index.

Consistency relationship facilitates the determination of possible events and measures logical inconsistencies of the decision maker/judgments (Cengiz and Akbulak 2009; Chen et al. 2010a, b). It represents the likelihood where the matrix judgments were formed randomly (Park et al. 2011; Saaty 1977). The CR mainly depends on the Consistency Index and Random Index.

$C I=\frac{\lambda_{\max }-n}{n-1}$

Equation 3 indicates the Consistency Index (CI) when $\lambda \max$ is the principle or highest eigenvector of the computed matrix and $\mathrm{n}$ denotes the order of the matrix. 
Fig. 7 Soil characteristics of the study area

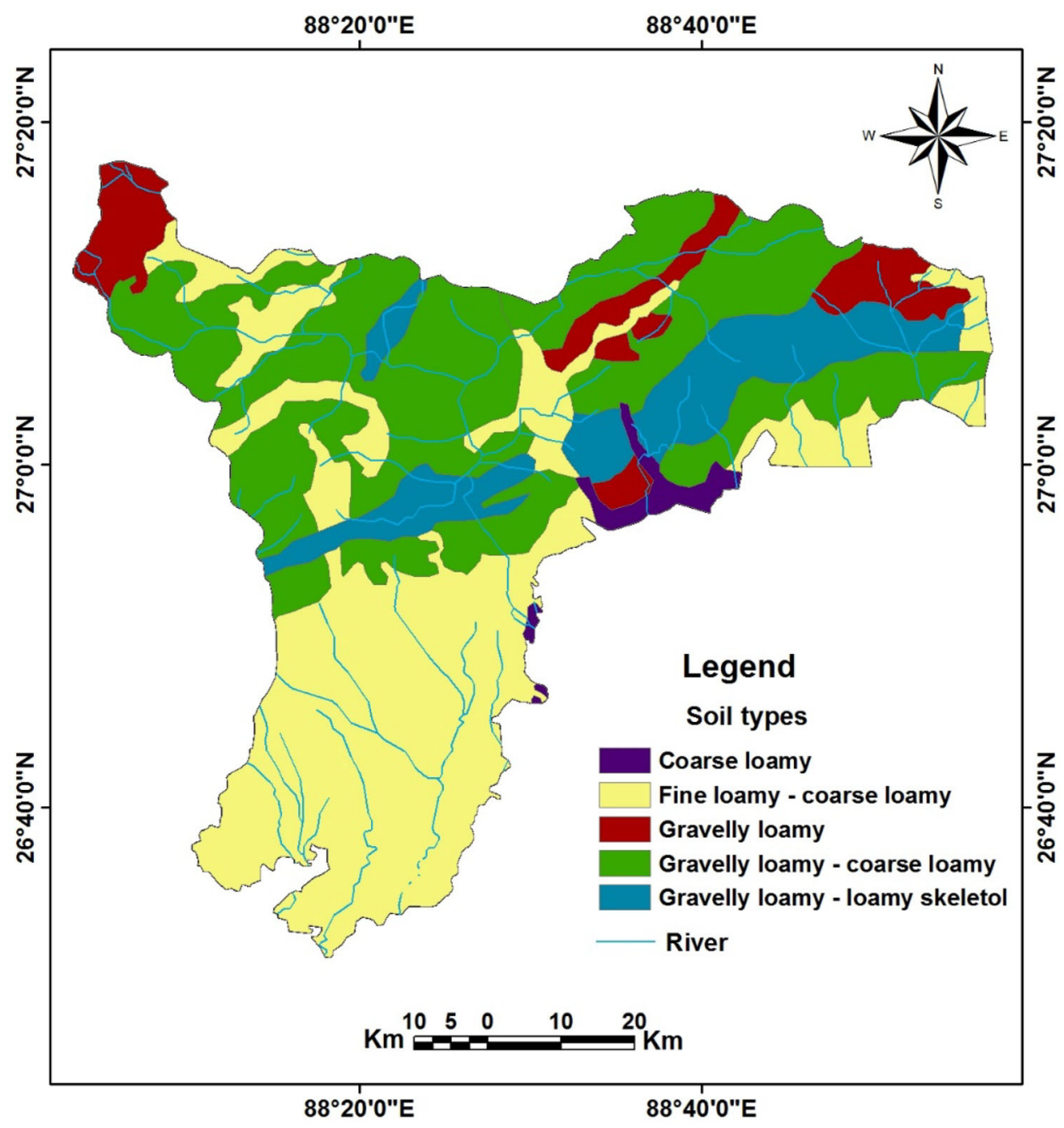

Random Index (RI) is the mean value of the consistency index depending on the computed matrix order given by Saaty (1977) that has shown in Table 7. If, the value of $\mathrm{CR}>0.10$, then the weight values of the matrix indicates inconsistencies and the method (AHP) may not give a meaningful results (Saaty 1980). In the present study the calculated CR was 0.0669 which is under acceptable limits and the computed weight values are valid. Further, the computed weight values are converted into percentage for weighted overlay analysis (WOA) in GIS, that shown in Table 8 .

\section{Site suitability model for agriculture using weighted overlay analysis}

The weighted overlay analysis is effective to resolve spatial complexity in suitability analysis and site selection based on general measurement of dissimilar and diverse impacts (Girvan et al. 2003; Kuria et al. 2011). Analytic hierarchy process is applied to determine the influential factors in the hierarchy of selected dissimilar inputs to weighted overlay analysis (Parimala and Lopez 2012). Moreover, all created thematic layer were combined with each other in GIS to applied the weighted overlay techniques (Girvan et al. 2003). Land suitability for agricultural development has been found using weighted overlay techniques based on analytic hierarchy process and multi-criterion decisionmaking process. Selected raster layers were overlaid by recognizing their cell values to the same scale, giving a weight value to individual criterion and integrating the weight cell values together (Eq. 4). The cell values of each raster layer are also multiplied by their weight value (Mojid et al. 2009; Cengiz and Akbulak 2009) using model builder toolbox of Arc-GIS 10.2.

$\mathrm{LS}=\sum_{i=1}^{n} W i X i$

Where, LS indicates the total land suitability score, Wi denotes the weight of the selected land suitability criteria, $\mathrm{Xi}$ indicates the assigned sub-criteria score of $\mathrm{i}$ land 
Fig. 8 Distance from rivers of the study area

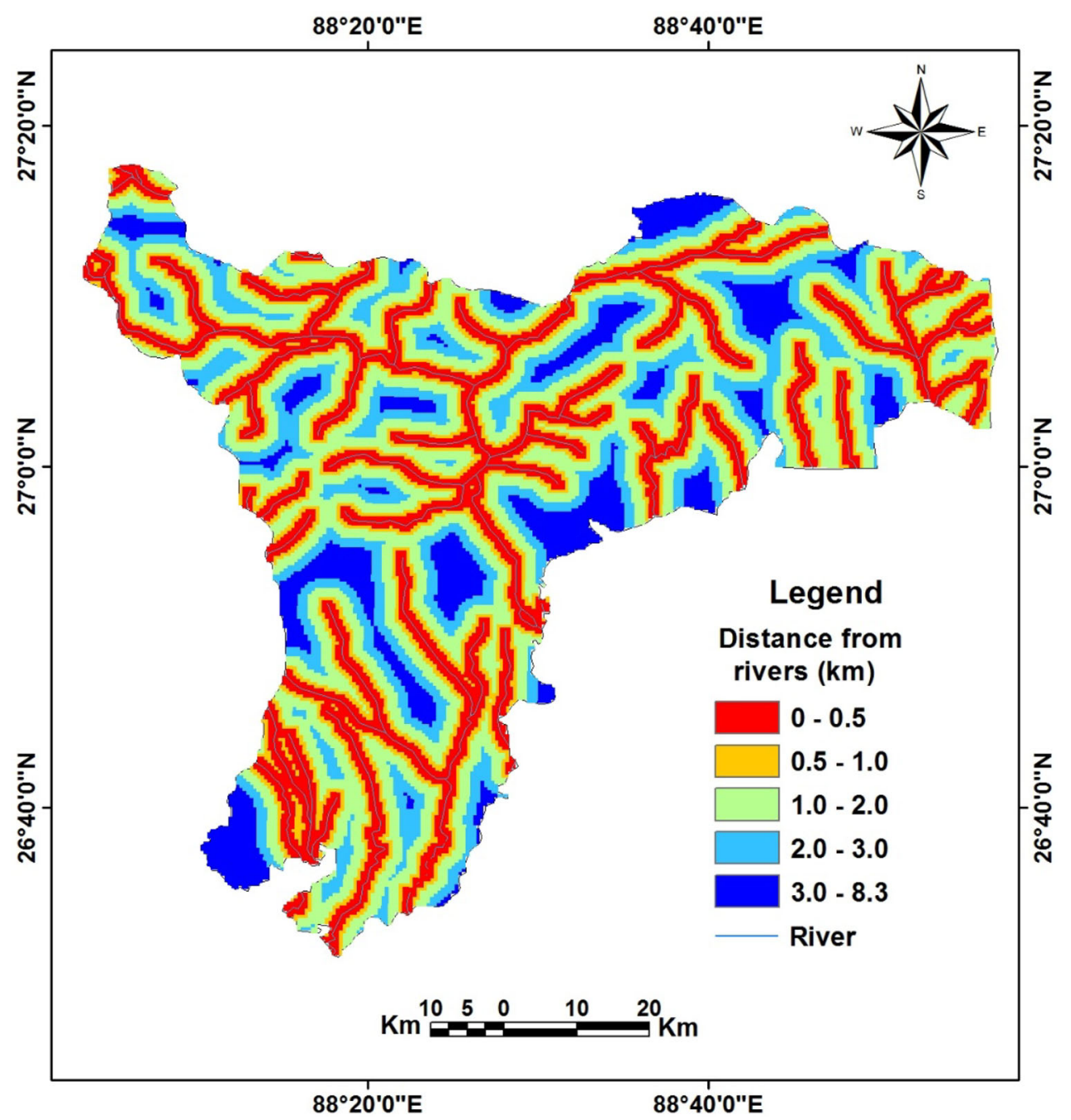

suitability criteria, and $\mathrm{n}$ denotes the total number of land capability criteria (Cengiz and Akbulak 2009).

\section{Results and discussion}

The weight values of selected parameters calculated in Analytic Hierarchy Process and designated scores of subcriterion were used in Weighted Overlay Analysis to generate the land suitability for agriculture in Darjeeling district (Table 8). According to the classification of Food and Agricultural Organization (FAO), land suitability for agriculture classified into five levels i.e., 1. Highly suitable agricultural land, 2. Moderately suitable agricultural land, 3. Marginally suitable agricultural land, 4. Currently not suitable for agriculture, and 5. Permanently not suitable for agricultural production (Table 9).
According to the generated land suitability map for agriculture, it was determined that $5.31 \%$ (16,722.94 ha) of the study area be highly suitable for agricultural production, $29.82 \%$ (93912.99 ha) is moderately suitable, $24.27 \%(76,434.21 \mathrm{ha})$ is marginally suitable land, $38.18 \%(120,241.38$ ha $)$ is currently not suitable land for agricultural production, and $2.42 \%$ (7621.37 ha) is permanently unsuitable (Fig. 13).

High elevation $(15-3209 \mathrm{~m})$, high slope $\left(3^{\circ}-89^{\circ}\right)$ with higher intensity of gully erosion, lower drainage availability of the study area were efficient factors, resulting in a less area/lower rate of highly suitable agricultural land in the Darjeeling district. Similarly, in a study of agricultural land suitability evaluation for the hilly areas of Ispir, Erzurum (Turkey), similar results were found, as a lower rate/less area of $0.4 \%$ area for highly suitable agriculture was computed (Akinci et al. 2013). The present study 
Fig. 9 Distance from roads of the study area

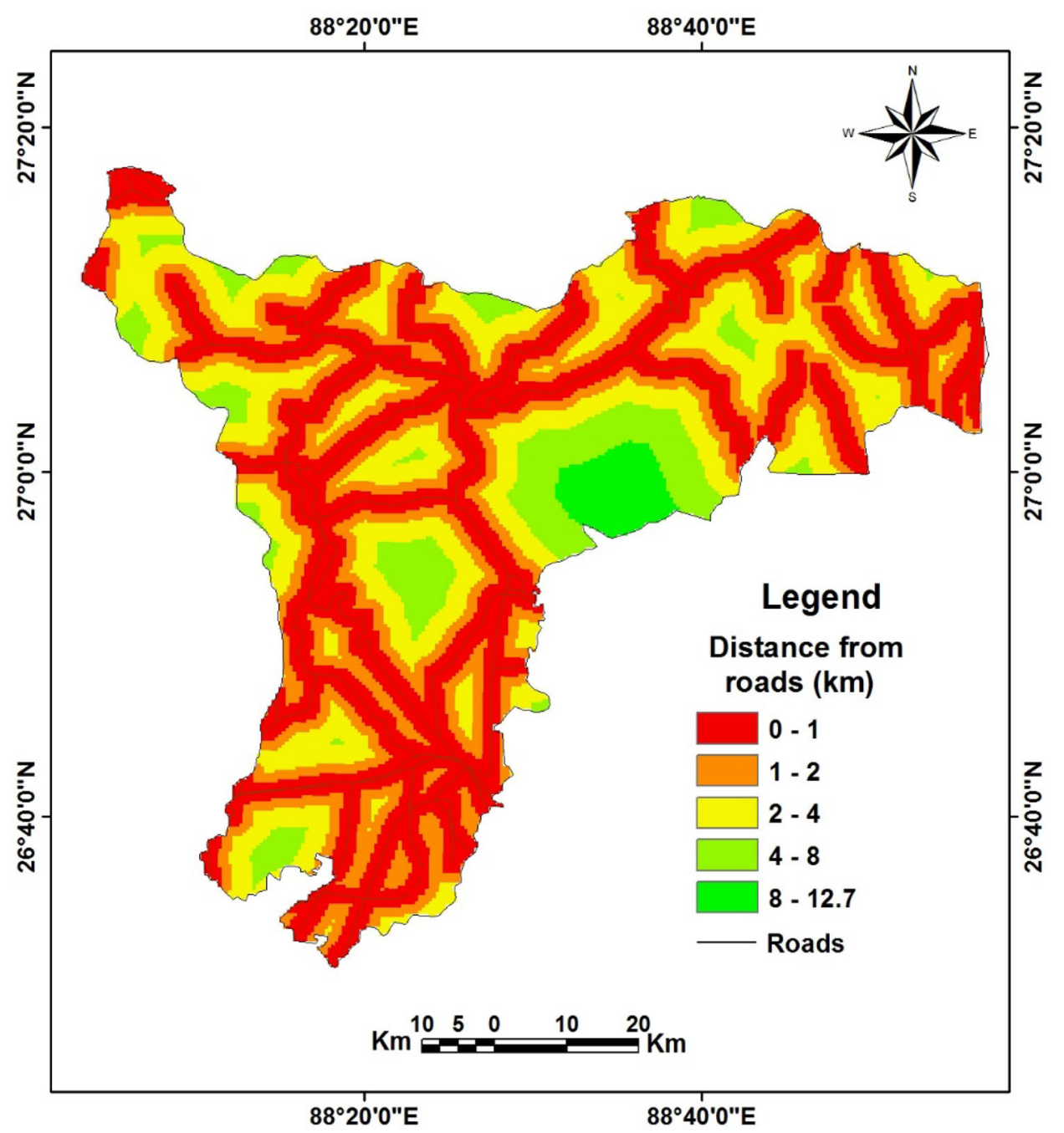

signifies that the large precipitous slope in Darjeeling district not only indicate the common characteristics of agricultural lands but also restrict potential agricultural production in the study region.

Vegetation/forest and tea plantation cover $64.91 \%$ (304,391.45 ha) of the study district (Table 9). While $18.6 \%(58,577.52 \mathrm{ha})$ of the study area that is marginally suitable land for agricultural production coincides with forest land/vegetal cover and tea plantation area, $1.8 \%$ (5668.79 ha) of highly suitable agricultural land and $6.5 \%$ (20,470.64 ha) of moderately suitable agricultural land coincide with forest land and tea plantation area. Because suitable land for agriculture cannot be carried out in dense vegetal cover and tea planted areas, under legal rules and regulations in Darjeeling district, these areas were eliminated from generating suitability map and another new agricultural suitability map was established, as shown in Fig. 14.
With the consideration of the waterbodies (River, reservoir, lakes, ponds, etc.) and barren lands of the Darjeeling district, Mirik reservoir, Senchal Lake and different perennial rivers in the study areas, it was computed that $12,376.85$ ha of suitable areas will be inundated/flooded (Table 9). It was established that the highly suitable land for agriculture production will be particularly damaged by this flooded condition. $0.40 \%$ (1259.73 ha) of this highly suitable agricultural land, $3.10 \%$ (9762.92 ha) of moderately suitable land, and $0.38 \%$ (1196.74 ha) of marginally suitable agricultural land will be lost due to inundation by waterbodies and sand deposition of the study area. Figure 15 shows the final agricultural suitability map generated by removing the waterbodies and barren lands of the Darjeeling district.

Therefore, the extent to which the recent agricultural/farming areas correspond to the suitability map of agriculture and how this agricultural land will be affected 
Fig. 10 LULC map of Darjeeling district $88^{\circ} 20^{\prime} 0 " E$

$8^{\circ} 40^{\prime} 0 " E$

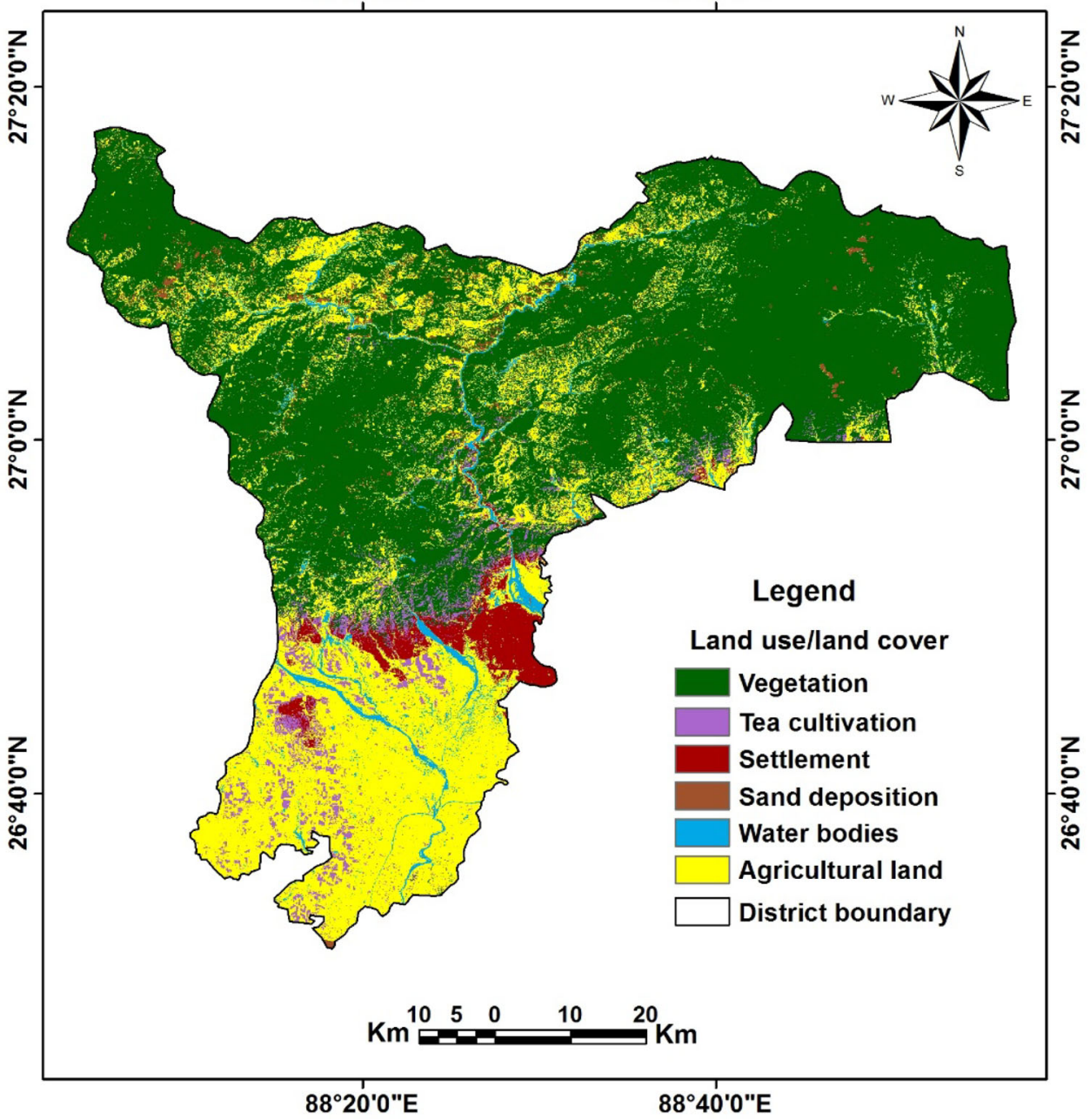

by the water bodies and barren lands were determined in the present study. Establishing the land use land cover map of the study shows that only $28.21 \%$ (88,843.95 ha) of the study area is recently used for agriculture. Also, it was determined that $29.82 \%(93,912.99$ ha) of the highly suitable lands, $5.31 \%(16,722.94 \mathrm{ha})$ of the moderately suitable lands, and $24.27 \%(76,434.21 \mathrm{ha})$ of the marginally suitable lands be currently used for agriculture in the Darjeeling district.

In recent, the construction of large dams and reservoirs appear to be imminent considering that dams and reservoirs help irrigation for hydroelectric power, drinking water, and agricultural production for rapid increasing population growth in the study region. Consequently, construction of large dams and reservoirs cover significant role in the
Darjeeling's investment budget that enforced to the different kind of environmental problems of Darjeeling district and its immediate environment (Bhutia 2014). However, it is also common characteristics that large reservoirs and dams can severally modify the river systems (both perennial and non-perennial river) they are built on and their surrounding environment. Also, large dams and reservoirs with entire drainage system can cause economic, social, and cultural losses as they immediate agricultural lands, cultural heritage and settlements (Bhutia 2014).

In the present study, it was established that agricultural activities are carried out in $38.18 \%$ (120,241.38 ha) of the area of this region is currently unsuitable for agriculture production and $2.42 \%$ (7621.38 ha) of the area that is permanently unsuitable for agricultural production. By 
Fig. 11 Soil moisture map of the study area

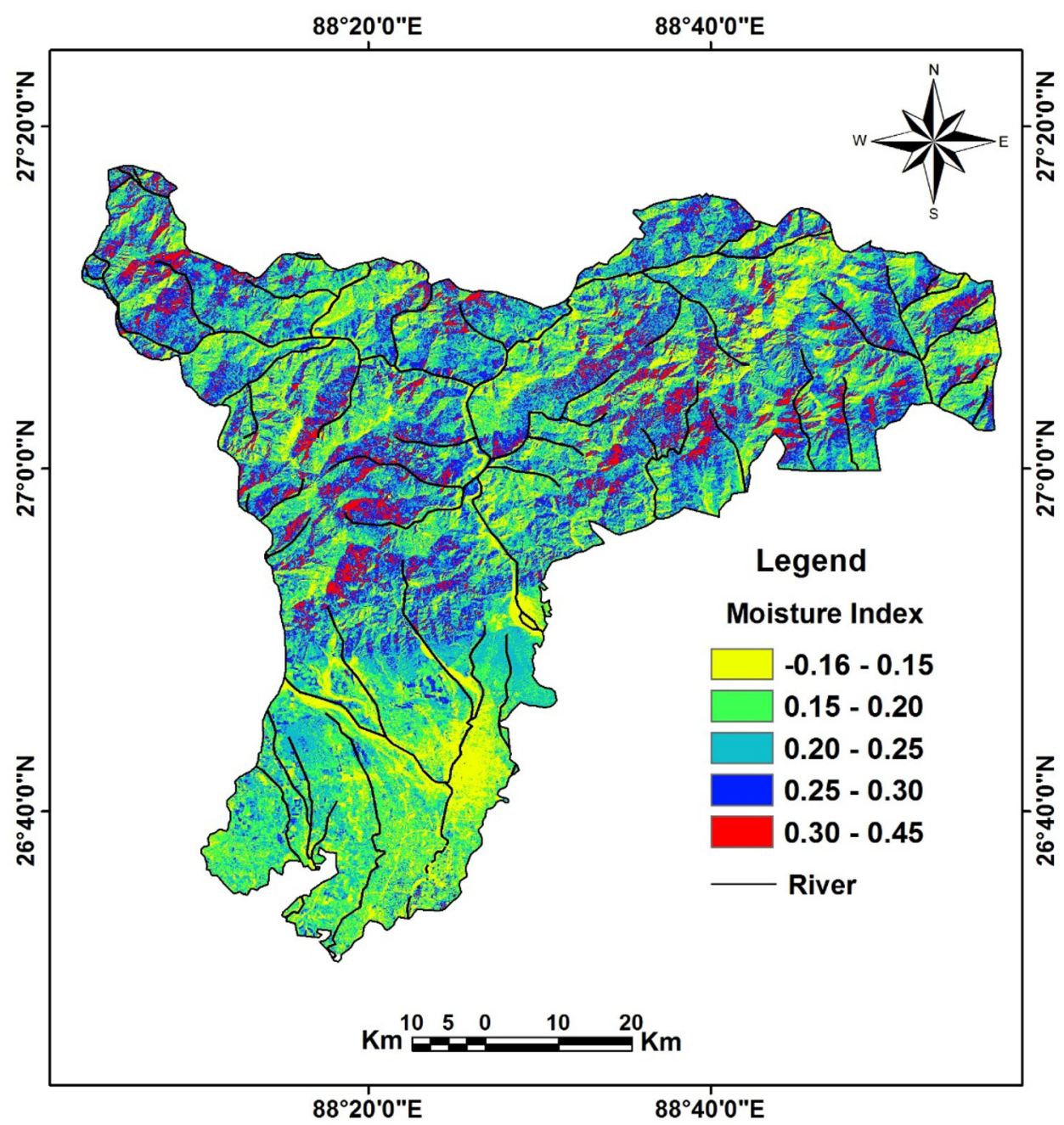

analyzing the physical qualities/characteristics of these areas, it was explored that $55.78 \%(175,669.57 \mathrm{ha})$ of the slope is higher than $20^{\circ}$ slope, $60.89 \%(191,767.14$ ha) of the land cover area is under dense vegetation cover, $51.97 \%(163,670.62 \mathrm{ha})$ lands is higher than $1000 \mathrm{~m}$ elevation, $45.19 \%(142,318.17 \mathrm{ha})$ area is under triassic geological formation, $56.87 \%(179,102.33$ ha) lands is under dry soil, $50.64 \%(159,482.02 \mathrm{ha})$ area is under coarse loamy to gravelly loamy in character in the study area. Also, it is well known that the local peoples utilise soil for their own means, to create terraces and carry out small amount of agricultural production on lands that are cureently and permanently unsuitable for agricultural production (Table 10).

\section{Conclusion}

The aim of this study was primarily focused on the identification of the suitable land for agriculture in the Darjeeling district which is mostly covered by tea cultivation and dense vegetation cover. Analytic hierarchy process with a combination of Geographic information system (GIS) is utilized for the evaluation in which nine different criteria were selected. The Analytic hierarchy process with integration of GIS was established very useful for the identification of the suitable site for agriculture. At the end of the evaluation, it was computed that only $5.31 \%$ (16,722.94 ha) of the study area is mostly suitable for farming, and $40.60 \%(127,862.76 \mathrm{ha})$ area is permanently 


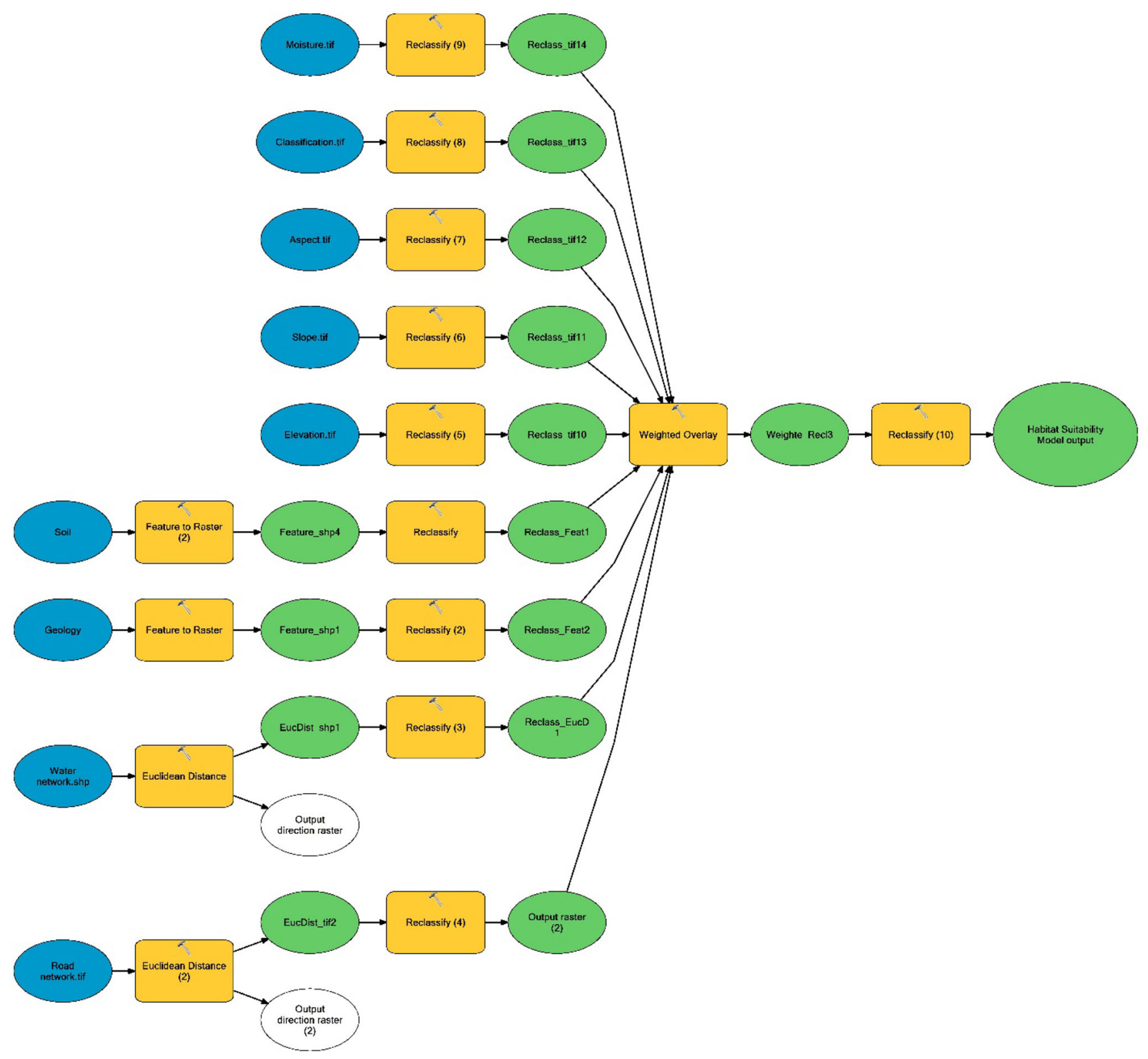

Fig. 12 Site suitability model for agriculture

and currently not suitable for agriculture production. However, the problems of the low production caused by geomorphological characteristics, such as very high elevation, a high degree of slope, less soil moisture, the presence of bare rocks, and low availability of the irrigation system. All these threats resulted in a very less amount of land in the study district being identified suitable for agricultural production.

The established result can be embraced by the decision-making process of the agricultural production in the study area, as it provides insight in establishing the suitable sites. The results can be more precise by 
Table 3 Areal and percentile distribution of the selected criteria and sub-criteria in the study

\begin{tabular}{|c|c|c|c|}
\hline Main criteria & Sub-criteria & Area (ha) & Area $(\%)$ \\
\hline \multirow[t]{5}{*}{ Slope $\left(^{\circ}\right)$} & $0-3$ & $48,184.73$ & 15.30 \\
\hline & $3-10$ & $40,311.41$ & 12.80 \\
\hline & $10-20$ & $50,767.18$ & 16.12 \\
\hline & $20-30$ & $37,414.03$ & 11.88 \\
\hline & $30-89$ & $138,255.54$ & 43.90 \\
\hline \multirow[t]{5}{*}{ Elevation (m) } & $15-150$ & $53,916.51$ & 17.12 \\
\hline & $150-500$ & $36,658.19$ & 11.64 \\
\hline & $500-1000$ & $60,687.57$ & 19.27 \\
\hline & $1000-1500$ & $48,468.17$ & 15.39 \\
\hline & $1500-3209$ & $115,202.45$ & 36.58 \\
\hline \multirow[t]{6}{*}{ LULC } & Agriculture & $88,843.95$ & 28.21 \\
\hline & Settlement & 9297.81 & 2.95 \\
\hline & Water bodies & 8936.82 & 2.84 \\
\hline & Sand deposition & 3429.30 & 1.09 \\
\hline & Tea cultivation & $12,657.87$ & 4.02 \\
\hline & Vegetation & $191,767.14$ & 60.89 \\
\hline \multirow[t]{5}{*}{ Soil moisture } & $<0.15$ & $30,170.57$ & 9.58 \\
\hline & $0.15-0.20$ & $35,807.87$ & 11.37 \\
\hline & $0.20-0.25$ & $69,852.12$ & 22.18 \\
\hline & $0.25-0.30$ & $167,890.72$ & 53.31 \\
\hline & $0.30-0.45$ & $11,211.61$ & 3.56 \\
\hline \multirow[t]{5}{*}{ Distance from river $(\mathrm{km})$} & $0-0.5$ & $45,066.90$ & 14.31 \\
\hline & $0.5-1.0$ & $50,094.78$ & 15.97 \\
\hline & $1.0-2.0$ & $73,127.42$ & 23.22 \\
\hline & $2.0-3.0$ & $47,145.45$ & 14.97 \\
\hline & $3.0-8.3$ & $99,298.34$ & 31.53 \\
\hline \multirow[t]{5}{*}{ Soil characteristics } & Fine loamy to coarse loamy & $107,801.53$ & 34.23 \\
\hline & Coarse loamy & $11,400.57$ & 3.62 \\
\hline & Gravel loamy to coarse loamy & $102,605.14$ & 32.58 \\
\hline & Gravel loamy & $41,445.17$ & 13.16 \\
\hline & Gravel loamy to loamy skeletal & $51,680.49$ & 16.41 \\
\hline \multirow[t]{5}{*}{ Geology } & Holocene & $63,553.46$ & 20.18 \\
\hline & Pleistocene (middle-upper) & $66,135.91$ & 21.00 \\
\hline & Pleistocene to Pliocene & $142,318.17$ & 45.19 \\
\hline & Cainozoic & $27,210.20$ & 8.64 \\
\hline & Triassic & $15,715.15$ & 4.99 \\
\hline \multirow[t]{5}{*}{ Aspect } & SW, flat & $119,674.50$ & 38.00 \\
\hline & $\mathrm{S}, \mathrm{SE}$ & $60,246.66$ & 19.13 \\
\hline & $\mathrm{E}, \mathrm{W}$ & $51,050.62$ & 16.21 \\
\hline & NW, NE & $44,090.60$ & 14.00 \\
\hline & $\mathrm{N}$ & $39,870.50$ & 12.66 \\
\hline \multirow[t]{5}{*}{ Distance from road $(\mathrm{km})$} & $0-1.0$ & $78,985.17$ & 25.08 \\
\hline & $1.0-2.0$ & $82,701.38$ & 26.26 \\
\hline & $2.0-4.0$ & $96,117.52$ & 30.52 \\
\hline & $4.0-8.0$ & $35,020.54$ & 11.12 \\
\hline & $8.0-12.7$ & $22,108.29$ & 7.02 \\
\hline
\end{tabular}


Table 4 The fundamental scale for pairwise comparison matrix (Saaty 1980)

\begin{tabular}{|c|c|c|c|c|c|c|c|c|c|c|c|}
\hline $\begin{array}{l}\text { Importance } \\
\text { rank }\end{array}$ & \multicolumn{5}{|l|}{ Definition } & \multicolumn{6}{|l|}{ Explanation } \\
\hline 1 & \multicolumn{5}{|c|}{ Equal importance } & \multicolumn{6}{|c|}{ Two criteria enrich equally to the objective criteria } \\
\hline 3 & \multicolumn{5}{|c|}{ Low importance of one over another } & \multicolumn{6}{|c|}{ Judgments and experience slightly favor one criteria over another } \\
\hline 5 & \multicolumn{5}{|c|}{ Strong or essential importance } & \multicolumn{6}{|c|}{ Judgments and experience strongly favor } \\
\hline 7 & \multicolumn{5}{|c|}{ Established importance } & \multicolumn{6}{|c|}{$\begin{array}{l}\text { A criteria is strongly favored and its dominance established in } \\
\text { practice }\end{array}$} \\
\hline 9 & \multicolumn{5}{|c|}{ Absolute or high importance } & \multicolumn{6}{|c|}{$\begin{array}{l}\text { The evidence favoring one criteria over another is of the highest } \\
\text { probable order of affirmation }\end{array}$} \\
\hline $2,4,6,8$ & \multicolumn{5}{|c|}{$\begin{array}{l}\text { Intermediate values between the two adjacent importance or } \\
\text { judgements }\end{array}$} & \multicolumn{6}{|c|}{ When adjustment is needed } \\
\hline Reciprocals & \multicolumn{11}{|c|}{$\begin{array}{l}\text { If criteria } \mathrm{i} \text { has one of the above numbers designated to it when compared with criteria } \mathrm{j} \text {, then } \mathrm{j} \text { has the reciprocal value when } \\
\text { compared with } \mathrm{i} \text {. }\end{array}$} \\
\hline \multirow{10}{*}{$\begin{array}{l}\text { Table } 5 \text { Pai } \\
\text { matrix for m } \\
\text { decision prob }\end{array}$} & $\begin{array}{l}\text { ise comparison } \\
\text { i-criteria }\end{array}$ & Criteria & Slope & Elevation & LULC & C Soil moisture & Drainage & Soil & Geology & Aspect & Road \\
\hline & & Slope & 1 & 2 & 2 & 3 & 4 & 6 & 8 & 9 & 9 \\
\hline & & Elevation & $1 / 2$ & 1 & 2 & 3 & 4 & 6 & 7 & 9 & 9 \\
\hline & & LULC & $1 / 2$ & $1 / 2$ & 1 & 2 & 3 & 4 & 5 & 7 & 8 \\
\hline & & Soil moisture & $1 / 3$ & $1 / 3$ & $1 / 2$ & 1 & 2 & 3 & 5 & 6 & 7 \\
\hline & & Drainage & $1 / 4$ & $1 / 4$ & $1 / 3$ & $1 / 2$ & 1 & 3 & 5 & 6 & 7 \\
\hline & & Soil & $1 / 6$ & $1 / 6$ & $1 / 4$ & $1 / 3$ & $1 / 3$ & 1 & 1 & 2 & 3 \\
\hline & & Geology & $1 / 8$ & $1 / 7$ & $1 / 5$ & $1 / 5$ & $1 / 5$ & 1 & 1 & 1 & 3 \\
\hline & & Aspect & $1 / 9$ & $1 / 9$ & $1 / 7$ & $1 / 6$ & $1 / 6$ & $1 / 2$ & 1 & 1 & 2 \\
\hline & & Road & $1 / 9$ & $1 / 9$ & $1 / 8$ & $1 / 7$ & $1 / 7$ & $1 / 3$ & $1 / 3$ & $1 / 2$ & 1 \\
\hline
\end{tabular}

Table 6 The synthesized matrix for multi-criteria decision making

\begin{tabular}{|c|c|c|c|c|c|c|c|c|c|c|}
\hline Criteria & Slope & Elevation & LULC & Soil moisture & Drainage & Soil & Geology & Aspect & Road & Weights \\
\hline Slope & 0.323 & 0.433 & 0.305 & 0.289 & 0.270 & 0.242 & 0.240 & 0.217 & 0.184 & 0.278 \\
\hline Elevation & 0.161 & 0.217 & 0.305 & 0.289 & 0.270 & 0.242 & 0.210 & 0.217 & 0.184 & 0.233 \\
\hline LULC & 0.161 & 0.108 & 0.153 & 0.192 & 0.202 & 0.161 & 0.150 & 0.169 & 0.163 & 0.162 \\
\hline Soil moisture & 0.108 & 0.333 & 0.076 & 0.096 & 0.135 & 0.121 & 0.150 & 0.145 & 0.143 & 0.117 \\
\hline Drainage & 0.081 & 0.054 & 0.051 & 0.048 & 0.067 & 0.121 & 0.150 & 0.145 & 0.143 & 0.095 \\
\hline Soil & 0.054 & 0.036 & 0.038 & 0.032 & 0.022 & 0.040 & 0.030 & 0.048 & 0.061 & 0.040 \\
\hline Geology & 0.040 & 0.031 & 0.031 & 0.019 & 0.013 & 0.040 & 0.030 & 0.024 & 0.061 & 0.032 \\
\hline Aspect & 0.034 & 0.024 & 0.022 & 0.016 & 0.011 & 0.020 & 0.030 & 0.024 & 0.041 & 0.024 \\
\hline Road & 0.034 & 0.024 & 0.019 & 0.014 & 0.010 & 0.013 & 0.010 & 0.012 & 0.021 & 0.019 \\
\hline
\end{tabular}

Maximum eigenvalue $\left(\lambda_{\max }\right)=9.782$

$\mathrm{n}=9$

Consistency index $(\mathrm{CI})=\left(\lambda_{\max }-\mathrm{n}\right) /(\mathrm{n}-1)=0.0977$

Random index $(\mathrm{RI})=1.46$

Consistency ratio $(\mathrm{CR})=(\mathrm{CI} / \mathrm{RI})=0.0669$

Table 7 Random inconsistency indices (RI) for $\mathrm{n}=10$

\begin{tabular}{lllllllllll}
\hline $\mathrm{n}$ & 1 & 2 & 3 & 4 & 5 & 6 & 7 & 8 & 9 & 10 \\
\hline $\mathrm{RI}$ & 0 & 0 & 0.58 & 0.90 & 1.12 & 1.24 & 1.32 & 1.41 & 1.46 & 1.49 \\
\hline
\end{tabular}


Table 8 Weights of the criteria and scores of the sub-criteria

\begin{tabular}{|c|c|c|c|c|}
\hline Main criteria & Weight & Influence (\%) & Sub-criteria & Score \\
\hline \multirow[t]{5}{*}{ Slope $\left(^{\circ}\right)$} & \multirow[t]{5}{*}{0.278} & \multirow[t]{5}{*}{27.8} & $0-3$ & 10 \\
\hline & & & $3-10$ & 8 \\
\hline & & & $10-20$ & 6 \\
\hline & & & $20-30$ & 4 \\
\hline & & & $30-89$ & 2 \\
\hline \multirow[t]{5}{*}{ Elevation (m) } & \multirow[t]{5}{*}{0.233} & \multirow[t]{5}{*}{23.3} & $15-150$ & 10 \\
\hline & & & $150-500$ & 6 \\
\hline & & & $500-1000$ & 4 \\
\hline & & & $1000-1500$ & 2 \\
\hline & & & $1500-3209$ & 1 \\
\hline \multirow[t]{6}{*}{ LULC } & \multirow[t]{6}{*}{0.162} & \multirow[t]{6}{*}{16.2} & Agriculture & 10 \\
\hline & & & Settlement & 1 \\
\hline & & & Water bodies & 1 \\
\hline & & & Sand deposition & 1 \\
\hline & & & Tea cultivation & 1 \\
\hline & & & Vegetation & 1 \\
\hline \multirow[t]{5}{*}{ Soil moisture } & \multirow[t]{5}{*}{0.117} & \multirow[t]{5}{*}{11.7} & $<0.15$ & 1 \\
\hline & & & $0.15-0.20$ & 2 \\
\hline & & & $0.20-0.25$ & 6 \\
\hline & & & $0.25-0.30$ & 8 \\
\hline & & & $0.30-0.45$ & 10 \\
\hline \multirow[t]{5}{*}{ Distance from river $(\mathrm{km})$} & \multirow[t]{5}{*}{0.065} & \multirow[t]{5}{*}{6.5} & $0-0.5$ & 10 \\
\hline & & & $0.5-1.0$ & 7 \\
\hline & & & $1.0-2.0$ & 5 \\
\hline & & & $2.0-3.0$ & 2 \\
\hline & & & $3.0-8.3$ & 1 \\
\hline \multirow[t]{5}{*}{ Soil characteristics } & \multirow[t]{5}{*}{0.040} & \multirow[t]{5}{*}{4.0} & Fine loamy to coarse loamy & 7 \\
\hline & & & Coarse loamy & 5 \\
\hline & & & Gravel loamy to coarse loamy & 3 \\
\hline & & & Gravel loamy & 2 \\
\hline & & & Gravel loamy to loamy skeletal & 1 \\
\hline \multirow[t]{5}{*}{ Geology } & \multirow[t]{5}{*}{0.032} & \multirow[t]{5}{*}{3.2} & Holocene & 10 \\
\hline & & & Pleistocene (middle-upper) & 7 \\
\hline & & & Pleistocene to Pliocene & 5 \\
\hline & & & Cainozoic & 3 \\
\hline & & & Triassic & 1 \\
\hline \multirow[t]{5}{*}{ Aspect } & \multirow[t]{5}{*}{0.024} & 2.4 & SW & 10 \\
\hline & & & $\mathrm{S}, \mathrm{SE}$ & 9 \\
\hline & & & $\mathrm{E}, \mathrm{W}$ & 5 \\
\hline & & & NW, NE & 3 \\
\hline & & & $\mathrm{N}$ & 1 \\
\hline Distance from road $(\mathrm{km})$ & 0.019 & 1.9 & $0-1.0$ & 10 \\
\hline & & & $1.0-2.0$ & 7 \\
\hline & & & $2.0-4.0$ & 4 \\
\hline & & & $4.0-8.0$ & 3 \\
\hline & & & $8.0-12.7$ & 1 \\
\hline
\end{tabular}


Table 9 Areal and percentile distribution of agricultural land suitability analysis results

\begin{tabular}{|c|c|c|c|c|}
\hline \multirow[t]{2}{*}{ Suitability level } & \multicolumn{2}{|c|}{ Suitable areas for agricultural production } & \multirow{2}{*}{$\begin{array}{l}\text { Suitable areas within vegetation } \\
\text { and tea garden (ha) }\end{array}$} & \multirow{2}{*}{$\begin{array}{l}\text { Areas to be inundated by } \\
\text { the water bodies (ha) }\end{array}$} \\
\hline & ha & $\%$ & & \\
\hline High suitability & $16,722.94$ & 5.31 & 5668.79 & 1259.73 \\
\hline Moderate suitability & $93,912.99$ & 29.82 & $20,470.64$ & 9762.92 \\
\hline Marginally suitable & $76,434.21$ & 24.27 & $58,577.52$ & 1196.74 \\
\hline Currently not suitable & $120,241.38$ & 38.18 & $112,116.11$ & 125.97 \\
\hline Permanently not suitable & 7621.37 & 2.42 & 7558.39 & 31.49 \\
\hline Total & $314,932.89$ & 100 & $204,391.45$ & $12,376.85$ \\
\hline
\end{tabular}

Fig. 13 Site suitability map for agriculture in Darjeeling district

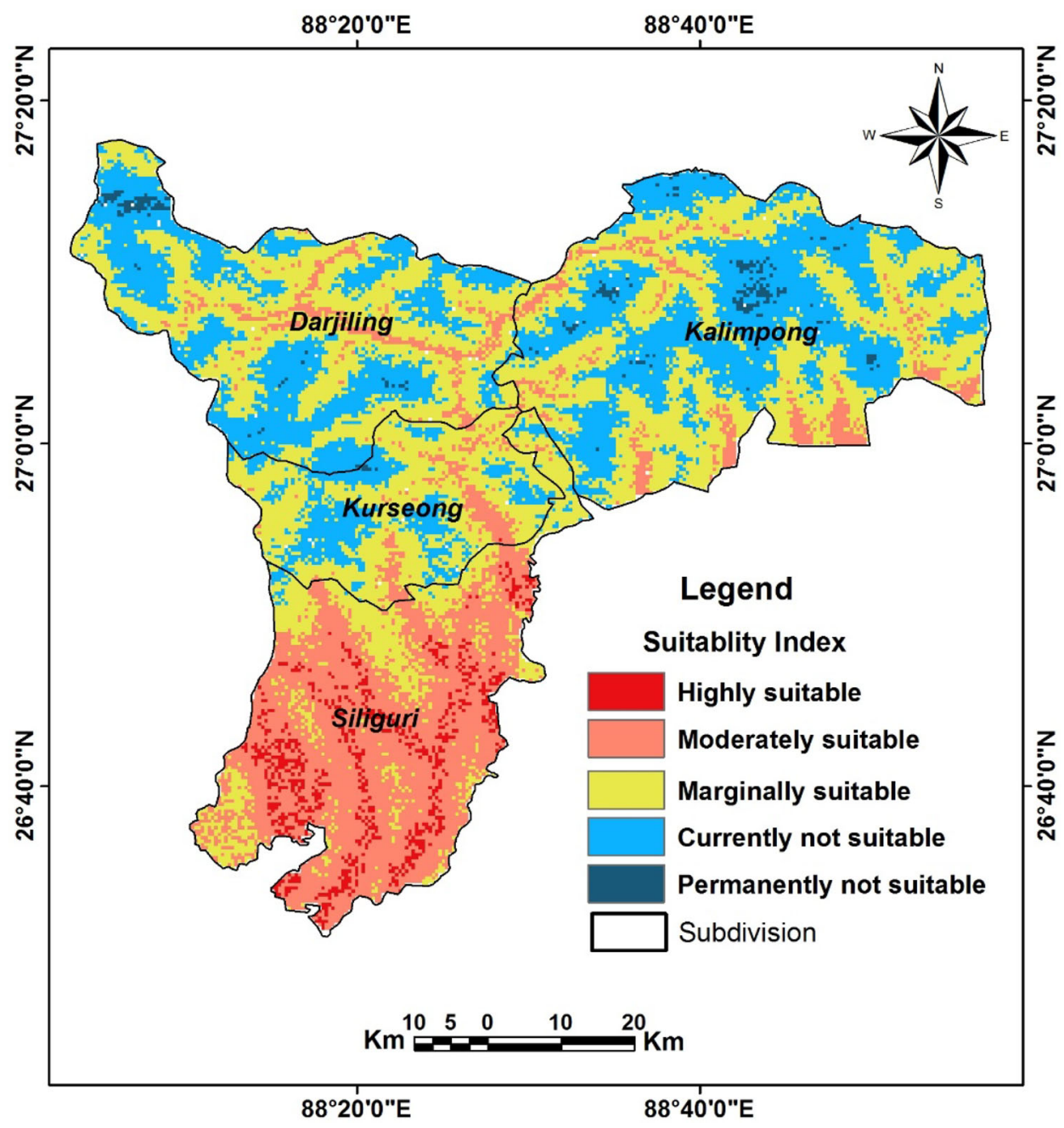


Fig. 14 Site suitability map obtained after removing vegetation and tea cultivated lands

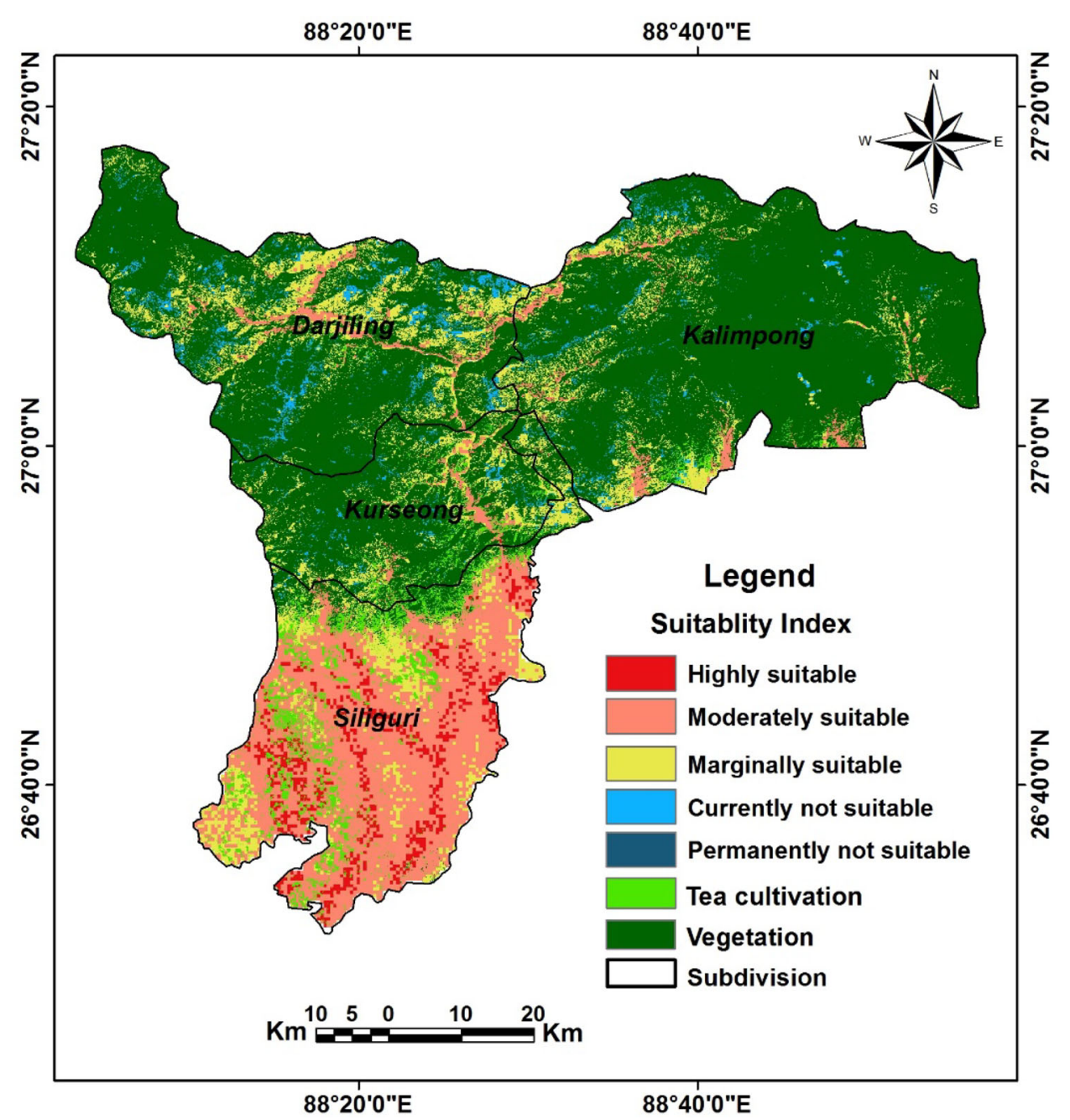

critically analyzing the methods and techniques utilised. The study also comprises the physical properties (topographical properties, soil and geological characteristics, etc.) only and need to include the economic and social criteria for agricultural production. Since in analytic hierarchy process, the pairwise comparison method is established on expert opinions which are mostly subjective in nature. Therefore, any wrong judgement on the any selected parameters can be efficiently conveyed to the score assignment and weights designation. This is the prime drawback of the analytic hierarchy process, and hence, weights and scores need to be designated carefully (Kritikos and Davies 2011; Nefeslioglu et al. 2013). For more beneficial and accurate results the study demands to be emphasized on some important species, like several medicinal plants/species which have significant economic value and also influences the scope of progress in rural tourism too. The utilisation of very high-resolution satellite image will aid in evaluating more finer areas. Also, the identified areas have to be documented on ground level with some other local and regional parameter before the final implementation. 
Fig. 15 Site suitability map obtained after removing water bodies and barren lands

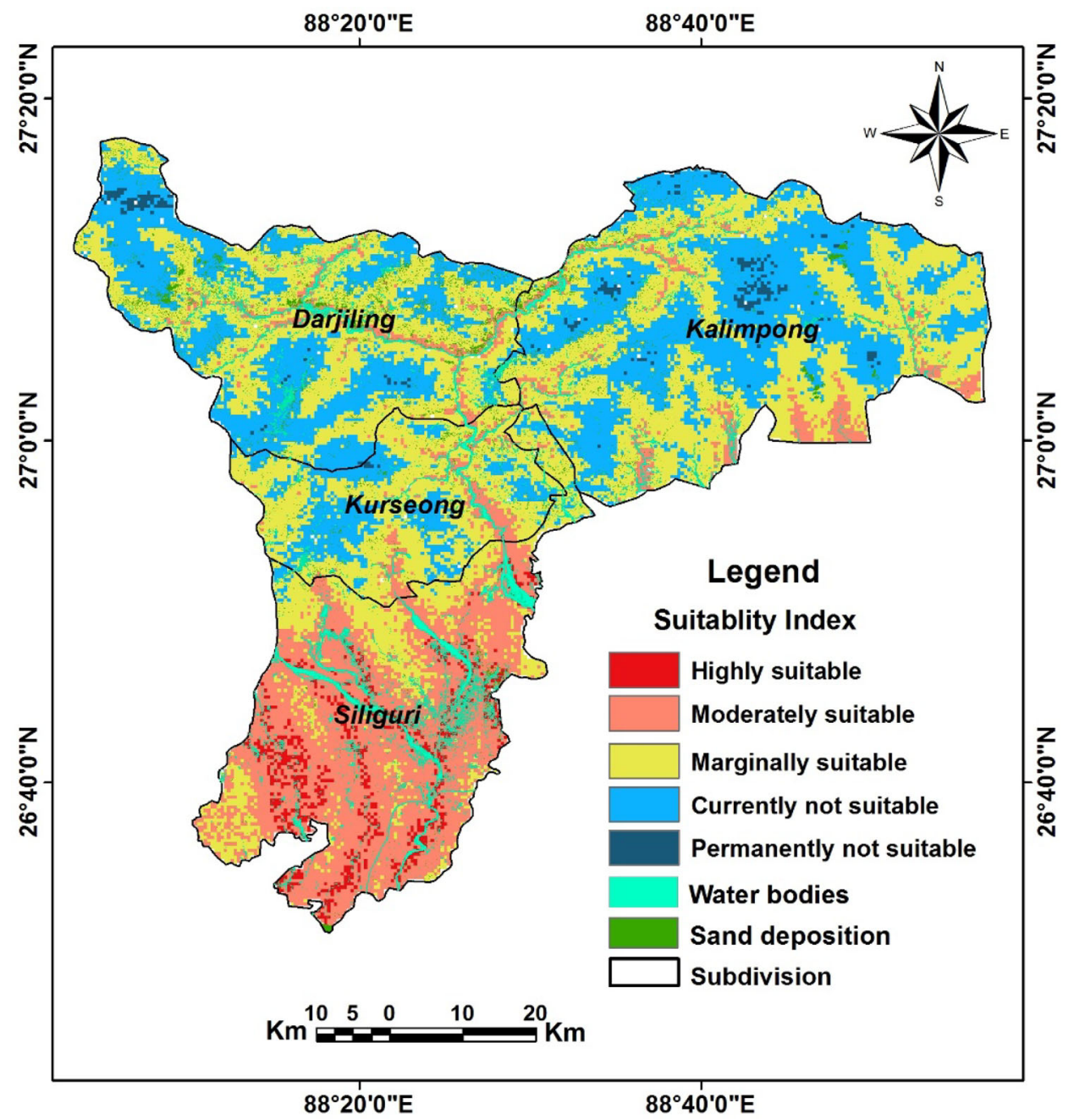

Table 10 Land suitability levels and their land characteristics

\begin{tabular}{|c|c|c|c|c|}
\hline $\begin{array}{l}\text { Suitability } \\
\text { classes }\end{array}$ & $\begin{array}{l}\text { Subdivisior } \\
\text { distribution } \\
\text { suitability }\end{array}$ & $\begin{array}{l}\text { wise } \\
\text { of land } \\
\text { ha) }\end{array}$ & Land qualities/characteristics & Remarks \\
\hline $\begin{array}{l}\text { Highly } \\
\text { suitable }\end{array}$ & $\begin{array}{l}\text { Darjeeling } \\
\text { Kalimpong } \\
\text { Curseong } \\
\text { Siliguri }\end{array}$ & $\begin{array}{l}15.51 \\
153.85 \\
180.61 \\
16,237.97\end{array}$ & $\begin{array}{l}\text { Gentle slopes }\left(0^{\circ}-3^{\circ}\right) \text { with gullies, high soil moisture } \\
\text { with lower elevation, fine loamy to coarse loamy } \\
\text { soil, good drainage capacity }\end{array}$ & $\begin{array}{l}\text { Most suitable for agriculture, favorable area for } \\
\text { intensive agriculture if irrigation facilities are } \\
\text { available }\end{array}$ \\
\hline $\begin{array}{l}\text { Moderately } \\
\text { suitable }\end{array}$ & $\begin{array}{l}\text { Darjeeling } \\
\text { Kalimpong } \\
\text { Curseong } \\
\text { Siliguri }\end{array}$ & $\begin{array}{l}6799.30 \\
8705.73 \\
4028.87 \\
74,379.09\end{array}$ & $\begin{array}{l}\text { Gentle to stiff slopes }\left(3^{\circ}-10^{\circ}\right) \text { with micro terracing, } \\
\text { medium soil moisture with lower elevation, coarse } \\
\text { loamy soil, moderate drainage capacity }\end{array}$ & $\begin{array}{l}\text { Suitable land for farming practices with proper } \\
\text { management, suitable for terrace cultivation }\end{array}$ \\
\hline $\begin{array}{l}\text { Marginally } \\
\text { suitable }\end{array}$ & $\begin{array}{l}\text { Darjeeling } \\
\text { Kalimpong } \\
\text { Curseong } \\
\text { Siliguri }\end{array}$ & $\begin{array}{l}25,605.46 \\
32,484.54 \\
13,146.68 \\
5197.53\end{array}$ & $\begin{array}{l}10^{\circ}-20^{\circ} \text { slope, less soil moisture with higher } \\
\text { elevation, coarse loamy to gravel loamy soil, low } \\
\text { drainage availability }\end{array}$ & $\begin{array}{l}\text { Less suitable land for agriculture with careful farm } \\
\text { management, necessary protections from drainage } \\
\text { and intensive erosion }\end{array}$ \\
\hline $\begin{array}{l}\text { Currently and } \\
\text { permanently } \\
\text { not suitable }\end{array}$ & $\begin{array}{l}\text { Darjeeling } \\
\text { Kalimpong } \\
\text { Curseong } \\
\text { Siliguri }\end{array}$ & $\begin{array}{l}49,355.02 \\
59,072.59 \\
17,900.79 \\
1539.35\end{array}$ & $\begin{array}{l}\text { Precipitous slope with rocky lands, dry soil, dense } \\
\text { forest, barren land, loamy skeletal soil, no drainage } \\
\text { availability }\end{array}$ & $\begin{array}{l}\text { The land is not suitable for agriculture, areas unde } \\
\text { dense vegetation, settlement, barren lands, open } \\
\text { rocks are not suitable for agriculture }\end{array}$ \\
\hline Total & $914,932.89$ & & & \\
\hline
\end{tabular}


Also, the study can be approved for rest of areas and also including other spheres of ecotourism than agriculture which can flourish in Darjeeling and its immediate surroundings.

\section{References}

Akinci H, Ozalp AY, Turgut B (2013) Agriculture land use suitability analysis using GIS and AHP technique. Comput Electron Agric 97:71-82

Bandyopadhyay S, Jaiswal RK, Hegde VS, Jayaraman V (2009) Assessment of land suitability potentials for agriculture using a remote sensing and GIS based approach. Int J Remote Sens 30(4):879-895

Bhutia S (2014) Economic development and environmental issues in Darjeeling Himalaya of West Bengal, India: a theoretical perspective. Int J Hum Soc Sci Invest 3(7):42-47

Boori MS, Vozenilek V, Choudhary K (2014) Land use/cover disturbance due to tourism in Jeseniky Mountain, Czech Republic: a remote sensing and GIS based approach. Egypt J Remote Sens Space Sci 18(1):17-26

Boroushaki S, Malczewski J (2008) Implementing an extension of the analytical hierarchy process using ordered weighted averaging operators with fuzzy quantifiers in ArcGIS. Comput Geosci 34(4):399-410

Bunruamkaew K, Murayam Y (2011) Site suitability evaluation for ecotourism using GIS and AHP: a case study of Surat Thani Province, Thailand. Procedia 21:269-278

Cengiz T, Akbulak C (2009) Application of analytical hierarchy process and geographic information systems in land-use suitability evaluation: a case study of Dumrek village. Int J Sustain Dev World Ecol 16(4):286-294

Chandio IA, Matori AN, Lawal DU, Sabri S (2011) GIS-based land suitability analysis using AHP for public parks planning in Larkana City. Mod Appl Sci 5(4):177-189

Chen H, Liu G, Yang Y, Ye X, Shi Z (2010a) Comprehensive evaluation of tobacco ecological suitability of Henan Province based on GIS. Agric Sci China 9(4):583-592

Chen Y, Yu J, Khan S (2010b) Spatial sensitivity analysis of multicriteria weights in GIS-based land suitability evaluation. Environ Model Softw 25(12):1582-1591

Darjeeling Climatological Table 1901-2000 (2015) Indian Meteorological Department. Government of India

Deep S, Saklani A (2014) Urban sprawl modeling using cellular automata. Egypt J Remote Sens Space Sci 17(2):179-187

District Census Handbook, Darjiling (2011) Census of India. Government of India

Duc TT (2006) Using GIS and AHP technique for land-use suitability analysis. In: International symposium on geo-informatics for spatial infrastructure development in earth and allied sciences, pp 1-6

Effat HA, Hassan OA (2013) Designing and evaluation of three alternatives highway routes using the analytical hierarchy process and the least-cost path analysis, application in Sinai Peninsula, Egypt. Egypt J Remote Sens Space Sci 16(2):141-151

FAO (1976) A framework for land evaluation, Soil Bulletin 32. Food and agriculture organization of the United Nations, Rome

Feizizadeh B, Blaschke T (2012) Land suitability analysis for Tabriz County, Iran: a multi criteria evaluation approach using GIS. J Environ Plan Manag 1:1-23

Feizizadeh B, Jankowski P, Blaschke T (2014) A GIS based spatiallyexplicit sensitivity and uncertainty analysis approach for multicriteria decision analysis. Comput Geosci 64:81-95
Garcia JL, Alvarado A, Blanco J, Jimenez E, Maldonado AA, Cortés G (2014) Multi-attribute evaluation and selection of sites for agricultural product warehouses based on an analytic hierarchy process. Comput Electron Agric 100:60-69

Girvan MS, Bullimore J, Pretty JN, Osborn AM, Ball AS (2003) Soil type is the primary determinant of the composition of the total and active bacterial communities in arable soils. Appl Environ Microbiol 69:1800-1809

Hopkins L (1977) Methods for generating land suitability maps: a evaluation. J. Am. Inst. Plan. 34(1):19-29

Jafari S, Zaredar N (2010) Land suitability analysis using multi attribute decision making approach. Int $\mathrm{J}$ Environ Sci Dev 1(5):441-445

Jankowski P (1995) Integrating geographical information system and multiple criteria decision making methods. Int J Geogr Inf Syst 9(3):251-273

Javadian M, Shamskooshki H, Momeni M (2011) Application of sustainable urban development in environmental suitability analysis of educational land use by using AHP and GIS in Tehran. Procedia Eng. 21:72-80

Joerin F, Theriault M, Musy A (2001) Using GIS and outranking multi-criteria analysis for land-use suitability assessment. Int $\mathbf{J}$ Geogr Inform Sci 15(2):153-174

Kamkar B, Dorri MA, Teixeira da Silva JA (2014) Assessment of land suitability and the possibility and performance of a canola (Brassica napus L.) - soybean (Glycine $\max$ L.) rotation in four basins of Golestan province, Iran. Egypt J Remote Sens Space Sci 17(1):95-104

Khahro SH, Matori AN, Chandio IA, Talpur MAH (2014) Land suitability analysis for installing new petrol filling stations using GIS. Procedia Eng 77:28-36

Kiker GA, Bridges TS, Varghese A, Seager TP, Linkov I (2005) Application of multicriteria decision analysis in environmental decision making. Integr Environ Asses Manag. 2:95-108

Kritikos TRH, Davies TRH (2011) GIS-based multi-criteria decision analysis for landslide susceptibility mapping at northern Evia, Greece. Z DTSCH Ges Geowiss 162(4):421-434

Kuria D, Ngari D, Withaka E (2011) Using geographic information systems (GIS) to determine land suitability for rice crop growing in the Tana delta. J Geogr Reg Plan 4(9):525-532

Lapple D, Cullinan J (2012) The development and geographic distribution of organic farming in Ireland. Ir Geog. 45(1):67-85

Malczewski J (1999) GIS and multicriteria decision analysis. Wiley, London

Malczewski J (2004) GIS-based land suitability: a critical overview. Progr Plan 62:3-65

Malczewski J (2006) GIS-based multi-criteria decision analysis: a survey of the literature. Int J Geogr Inf Sci 20(7):703-726

Mendas A, Delali A (2012) Integration of multi-criteria decision analysis in GIS to develop land suitability for agriculture: application to durum wheat cultivation in the region of Mleta in Algeria. Comput Electron Agric 83:117-126

Miller W, Collins W, Steiner FR, Cook E (1998) An approach for greenway suitability analysis landscape and urban planning. Int $\mathbf{J}$ Geogr Inform Sci 42(2-4):91-105

Mojid MA, Mustafa SMT, Wyseure GCL (2009) Growth, yield and water use efficiency of wheat in silt loam-amended loamy sand. J Bangladesh Agric Univ 7(2):403-410

Mokarram M, Aminzadeh F (2010) GIS-based multi-criteria land suitability evaluation using ordered weight averaging with fuzzy quantifier: a case study in Shavur Plain, Iran. Int Arch Photogram Remote Sens Spat Inf Sci 38(2):508-512

Nefeslioglu HA, Sezer EA, Gokceoglu C, Ayas Z (2013) A modified analytical hierarchy process (M-AHP) approach for decision support systems in natural hazard assessments. Comput Geosci $59: 1-8$ 
Parimala M, Lopez D (2012) Decision making in agriculture based on land suitability-spatial data analysis approach. J Theor Appl Inf Technol 46(1):17-23

Park S, Jeon S, Kim S, Choi C (2011) Prediction and comparison of urban growth by land suitability index mapping using GIS and RS in South Korea. Landsc Urban Plan 99(2):104-114

Roig-Tierno N, Baviera-Puig A, Buitrago-Vera J, Mas-Verdu F (2013) The retail site location decision process using GIS and the analytical hierarchy process. Appl Geogr 40:191-198

Saaty TL (1977) A scaling method for priorities in hierarchical structures. J Math Psychol 15:234-281

Saaty TL (1980) The analytic hierarchy process: planning, priority setting, resource allocation. McGraw Hill International, New York

Shalaby A, Ouma YO, Tateishi R (2006) Land suitability assessment for perennial crops using remote sensing and geographic information systems: a case study in North-western Egypt. Arch Agron Soil Sci 52(3):243-261

Steiner F, McSherry L, Cohen J (2000) Land suitability analysis for the upper Gila River watershed. Landsc Urban Plan 50:199-214

Tiwari DN, Loof R, Paudyal GN (1999) Environmental-economic decision-making in lowland irrigated agriculture using multicriteria analysis techniques. Agric Syst 60(2):99-112
Triantaphyllou E, Mann SH (1995) Using the analytic hierarchy process for decision making in engineering applications: some challenges. Int. J. Ind. Eng. Appl. Pract. 2(1):35-44

Wang F (1994) The use of artificial neural networks in a geographical information system for agricultural land-suitability assessment. Environ Plan A 26(2):265-284

Wang F, Hall GB, Subaryono (1990) Fuzzy information representation and processing in conventional GIS software: data base design and applications. Int J Geogr Inform Syst 4(3):261-283

Xu Y, Sun J, Zhang J, Xu Y, Zhang M, Liao X (2012) Combining AHP with GIS in synthetic evaluation of environmental suitability for living in China's 35 major cities. Int J Geogr Inf Sci 26(9):1603-1623

Yu J, Chen Y, Wu J, Khan S (2011) Cellular automata-based spatial multi-criteria land suitability simulation for irrigated agriculture. Int J Geogr Inf Sci 25(1):131-148

Zolekar RB, Bhagat VS (2014) Use of IRS P6 LISS-IV data for land suitability analysis for cashew plantation in hilly zone. Asian $\mathbf{J}$ Geoinform 14(3):23-35 